\title{
Integrated Solutions for the Water-Energy-Land Nexus: Are Global Models Rising to the Challenge?
}

\author{
Nils Johnson ${ }^{1}$, Peter Burek ${ }^{1}\left(\mathbb{D}\right.$, Edward Byers ${ }^{1}\left(\mathbb{D}\right.$, Giacomo Falchetta $^{2} \oplus$, Martina Flörke ${ }^{3}$, \\ Shinichiro Fujimori ${ }^{4}{ }^{(0)}$, Petr Havlik ${ }^{1}$, Mohamad Hejazi ${ }^{5}$, Julian Hunt ${ }^{1}$, Volker Krey ${ }^{1,6}{ }^{\circledR}$, \\ Simon Langan ${ }^{1}$, Nebojsa Nakicenovic ${ }^{1}$, Amanda Palazzo ${ }^{1} \oplus$, Alexander Popp ${ }^{7}$, Keywan Riahi ${ }^{1}$, \\ Michiel van Dijk ${ }^{1,8}$ (®) Michelle T.H. van Vliet ${ }^{9}$, Detlef P. van Vuuren ${ }^{10,11}$, Yoshihide Wada ${ }^{1,9}$, \\ David Wiberg ${ }^{12}$, Barbara Willaarts ${ }^{1}\left(\mathbb{D}\right.$, Caroline Zimm ${ }^{1}(\mathbb{D})$ and Simon Parkinson ${ }^{1,13, *(\mathbb{D})}$ \\ 1 International Institute for Applied Systems Analysis (IIASA), A-2361 Laxenburg, Austria; \\ johnsonn@iiasa.ac.at (N.J.); burek@iiasa.ac.at (P.B.); byers@iiasa.ac.at (E.B.); havlik.petr@gmail.com (P.H.); \\ hunt@iiasa.ac.at (J.H.); krey@iiasa.ac.at (V.K.); langan@iiasa.ac.at (S.L.); naki@iiasa.ac.at (N.N.); \\ palazzo@iiasa.ac.at (A.P.); riahi@iiasa.ac.at (K.R.); vandijkm@iiasa.ac.at (M.v.D.); wada@iiasa.ac.at (Y.W.); \\ willaart@iiasa.ac.at (B.W.); zimmc@iiasa.ac.at (C.Z.) \\ 2 Fondazione Eni Enrico Mattei (FEEM), 20123 Milano, Italy; giacomo.falchetta@feem.it \\ 3 Institute of Hydrological Engineering and Water Management, Ruhr-Universität Bochum, 44780 Bochum, \\ Germany; martina.floerke@hydrology.ruhr-uni-bochum.de \\ 4 Department of Environmental Engineering, Kyoto University, Kyoto 606-8501, Japan; \\ sfujimori@athehost.env.kyoto-u.ac.jp \\ 5 Joint Global Change Research Institute (JGCRI), Pacific Northwest National Laboratory, College Park, MD \\ 20740, USA; Mohamad.Hejazi@pnnl.gov \\ 6 Norwegian University of Science and Technology, 7491 Trondheim, Norway \\ 7 Potsdam Institute for Climate Impact Research (PIK), 14473 Potsdam, Germany; popp@pik-potsdam.de \\ 8 Wageningen Economic Research, 2595 BM Den Haag, The Netherlands \\ 9 Department of Physical Geography, Faculty of Geosciences, Utrecht University, 3584 CB Utrecht, The \\ Netherlands; m.t.h.vanvliet@uu.nl \\ 10 PBL Netherlands Environmental Assessment Agency, 2594 AV Den Haag, The Netherlands; \\ Detlef.vanVuuren@pbl.nl \\ 11 Copernicus Institute for Sustainable Development, Utrecht University, 3584 CB Utrecht, The Netherlands \\ 12 International Water Management Institute (IWMI), 10120 Colombo, Sri Lanka; wiberg@iiasa.ac.at \\ 13 Institute for Integrated Energy Systems (IESVic), University of Victoria, Victoria, BC V8P 5C2, Canada \\ * Correspondence: parkinso@iiasa.ac.at
}

Received: 21 September 2019; Accepted: 21 October 2019; Published: 25 October 2019

\begin{abstract}
Increasing human demands for water, energy, food and materials, are expected to accentuate resource supply challenges over the coming decades. Experience suggests that long-term strategies for a single sector could yield both trade-offs and synergies for other sectors. Thus, long-term transition pathways for linked resource systems should be informed using nexus approaches. Global integrated assessment models can represent the synergies and trade-offs inherent in the exploitation of water, energy and land (WEL) resources, including the impacts of international trade and climate policies. In this study, we review the current state-of-the-science in global integrated assessment modeling with an emphasis on how models have incorporated integrated WEL solutions. A large-scale assessment of the relevant literature was performed using online databases and structured keyword search queries. The results point to the following main opportunities for future research and model development: (1) improving the temporal and spatial resolution of economic models for the energy and water sectors; (2) balancing energy and land requirements across sectors; (3) integrated representation of the role of distribution infrastructure in alleviating resource challenges; (4) modeling of solution impacts on downstream environmental quality; (5) improved representation of the implementation challenges stemming from regional financial and institutional capacity; (6) enabling dynamic multi-sectoral vulnerability and adaptation needs assessment; and (7) the development of fully-coupled assessment
\end{abstract}


frameworks based on consistent, scalable, and regionally-transferable platforms. Improved database management and computational power are needed to address many of these modeling challenges at a global-scale.

Keywords: integrated assessment modeling; global change; sustainable development; water futures; energy transformations; land-use change

\section{Introduction}

Water, energy and land (WEL) represent fundamental resources needed for human survival and are critical for supporting economic development and ecosystem services, such as flood control, carbon sequestration and biodiversity. Socioeconomic and climate trends are rapidly increasing global demands for WEL resources. Based on the "middle-of-the-road" Shared Socioeconomic Pathway (SSP2) scenario in which population reaches about 9 billion in 2050, food demand is projected to increase on average $74 \%$ (59-98\%) from 2005 to 2050 [1], primary energy supply will increase on average $92 \%(81-113 \%)$ [2], agricultural land is projected to increase on average 5\% (3-7\%) [3], and global water demand is projected to increase about 50\% [4,5]. Meanwhile, WEL resources are regionally constrained for physical or economic reasons and several global "mega-trends", such as climate change, urbanization, and globalization, are expected to have regional impacts that may either exacerbate or alleviate resource constraints and the associated supply challenges [6]. There is an urgent need to better understand the impacts and vulnerability of human populations and ecosystems to future socioeconomic and climatic change as well as to identify sustainable strategies for meeting future demands for WEL resources while adapting to environmental challenges.

Integrated models of WEL systems are needed to quantify future challenges and to design least-cost policies that leverage feedbacks in the linkages across resource supply and consumption [7]. Models with global-scope are particularly important for capturing the influence of globalization and international trade, which are an increasingly critical aspect in the local pricing of fuel, food and materials $[8,9]$. National and international policy-makers are mainly using knowledge generated from global models to inform target setting in the context of climate change mitigation and adaptation [10], but there is further scope to apply the frameworks to study policy designs for a broader set of targets consistent with the sustainable development agenda [11-13].

This paper reviews the challenges and opportunities for global models integrating resource management decisions (or solutions) across WEL systems. The review aims to answer the following research questions: (1) how are impacts and adaptation strategies currently represented in global models; and (2) what are the main opportunities for future research and model development? Global models are widely used to examine the long-term implications of socioeconomic and climatic change for the demand, availability, and management of WEL resources. Global-scale assessments incorporating multiple models have also become routine for addressing uncertainties across modeling assumptions and outcomes [14-17]. Yet, there is growing concern that WEL interdependencies could fundamentally alter the transition strategies identified by global models. The concept of nexus thinking has gained traction within the global modeling community, and some first efforts have been made to improve the representation of nexus linkages within individual models. The end goal is to develop integrated assessment frameworks that endogenously consider the trade-offs and synergies among water, food, and energy systems to design sustainable transformation pathways.

The focus of the literature review was on global-scale studies that assess water, energy and land systems under impacts of global change and that had been applied to study at least one connection in the water-energy-land nexus. To identify key literature, we leveraged the diverse knowledge of the author team and conducted a systematic literature review using structured keyword search queries in Google Scholar and Scopus. No specific timeframe for the article selection was used, but emphasis 
was placed on the most recent and those that included solution pathways that specifically address challenges in the water-energy-land nexus. Approximately, 400 articles were initially identified and categorized based on geographic scope and treatment of nexus solutions. The review identified the major types of global models that address the nexus and how these models have currently been upgraded and applied to conduct nexus assessments. Additionally, the review synthesized the key limitations of current efforts, and highlighted several research opportunities and model developments that are needed to improve global-scale nexus assessments. Nexus assessments are particularly needed in the context of the Sustainable Development Goals (SDGs), where a global framework would be useful to identify strategies for addressing multiple goals while avoiding efforts that are counterproductive across sectors and countries $[11,18,19]$. However, existing global models have limitations that impede coordinated assessment across resources and, thus, many opportunities exist for model improvement.

The paper proceeds as follows. In Section 2 we review global models used to assess impacts of global change on the water-energy-land nexus. In Section 3 we move to the integrated assessment frameworks developing solution pathways. We present the critical areas for model improvement in Section 4. Conclusions from the research are summarized in Section 5.

\section{Assessing the Vulnerability of Human and Natural Systems to Global Change}

\subsection{Land Productivity and the Influence of Climate and Water Constraints}

Global gridded crop models (GGCs) quantify the implications of climate change for crop productivity, although the scope may extend beyond agricultural systems to include forestry and other land uses. The models are gridded because the calculations are made for pixels or raster cells representing the terrestrial area of the earth's surface. Examples of commonly used GGCs are LPJmL (Lund-Potsdam-Jena managed Land; [20,21]), EPIC (Environmental Policy Integrated Climate; [22]), PEGASUS (Predicting Ecosystem Goods and Services Using Scenarios; [23]), and GAEZ (global agro-ecosystem zone; [24]). Some of these models (e.g., LPJmL and EPIC) include both a global vegetation and water balance model that represent both natural and agricultural vegetation, river routing, and both water availability and agricultural water demands; thus, these frameworks can be classified as both a GGC and gridded hydrological model (GHM-Covered in the following section). GGCs are designed to simulate the productivity of specific crops under different climate, soil, and management environments within each land-occupied grid cell on the planet. The global models contribute to nexus assessment through applications that explore the implications of water constraints and water management interventions for crop yields and irrigation water use [25-29].

Implications of climate change for crop yields and irrigation water use have been compared across several climate models and Representative Concentration Pathways (RCPs) [25,28-30]. Each RCP represents a specific projection of future global GHG emissions and climate forcing trajectory [31]. Although there is significant variability among GGCs, they generally predict that climate change will reduce crop yields in low-latitude regions and increase yields in high-latitude regions [32]. At the global level, significant uncertainty remains regarding the direction of change with impacts on future agricultural production in the range of $\pm 10 \%$ by the end of the century [25]. Furthermore, GGCs project an $8-15 \%$ decline in irrigation water requirements on existing irrigated lands over the course of the century in response to a high GHG emissions scenario [26]. The projected water requirements are much smaller than the $25-40 \%$ increase predicted by GHMs covered in the following section. Much of this difference can be attributed to the inclusion in GGCs of: (1) $\mathrm{CO}_{2}$ fertilization effects; (2) shortened growing seasons in response to warming; and (3) single cropping cycles per year, which all reduce water requirements [26].

GGCs assess crop productivity as well as agricultural water and fertilizer requirements based on a combination of the biophysical properties (e.g., soil, climate) and human-driven management decisions (e.g., water interventions, fertilization, crop choice). However, these models do not typically have an explicit economic component and thus cannot optimize management responses to changes in climate 
and food demands $[33,34]$. Rather, they estimate static productivity impacts under pre-specified management regimes or, alternatively, the resource requirements required to alleviate gridded resource constraints (e.g., the fertilizer and irrigation required to avoid nitrogen and water stress, respectively).

GGCs play an important role in agro-economic models by providing a large number of gridded inputs under specific biophysical properties and management regimes, including the productivity of individual crops, resource requirements (e.g., water, nutrients, carbon), and environmental impacts (e.g., soil erosion) [35,36]. GGCs are valuable for quantifying the use of nexus-relevant resources (e.g., fertilizer and irrigation water) required to meet future food and bioenergy demands under specific management regimes and climates. GGCs have been used to assess the implications of local renewable water constraints and water management interventions for food production and agricultural water use $[26,29]$. Improved water management interventions (e.g., switching to more efficient irrigation systems) could mitigate water scarcity risks and halve the global food gap by 2050 without requiring additional cropland [27]. These interventions are important for maintaining the required environmental flows to support healthy riverine ecosystems [37]. However, GGCs do not consider non-local (e.g., intra- and interbasin transfers) or unconventional (e.g., fossil groundwater and desalination) water resources. Given that over $50 \%$ of global irrigation water withdrawals are estimated to come from unconventional or non-local water resources [21], it is important to consider investments into water supply technologies that could make these resources accessible when assessing the climate-water-food nexus. In areas where technologies could affordably improve sustainable access to these resources, GGCs are likely to overestimate the impacts of climate change on crop productivity. In Africa and other developing regions, the vast majority of cropland is still rainfed, and thus increasing demand for irrigation via e.g., water pumping might enormously increase pressure on water resources in areas prone to climate change impacts [38].

\subsection{Global Hydrological Models (GHMs)}

GHMs are designed to study evolution of water availability over time to identify the populations, sectors, and locations that will be most affected by water allocation and water scarcity. Examples of major GHMs that include both an accounting of water availability and demand are WaterGAP (Water-A Global Assessment and Prognosis; [39,40]), PCR-GLOBWB [41], H08 [4,42], WBM (Water Balance Model; [43]) and the water module of GCAM (Global Change Assessment Model; [44]). These models include both hydrological modules and water demand modules and, like GGCs, typically operate at gridded spatial resolutions as fine as 30-arcminutes or 5-arcminutes [5]. 30-arcminutes is equivalent to 0.5 -degree grid resolution and is approximately $50 \times 50 \mathrm{~km}$ at the equator; 5 -arcminutes is equivalent to 0.083 -degree grid resolution and is approximately $9 \times 9 \mathrm{~km}$ at the equator. GHMs estimate the renewable freshwater resources (i.e., surface runoff and baseflow) within each grid cell based on climate inputs that influence the daily water balances of both vegetation and soil.

The demand modules embedded in GHMs simulate future municipal, industrial, and agricultural water withdrawals and consumption and thus can address nexus challenges through their multi-sectoral representation of water demands. River runoff and water consumption estimates are included in a river routing model to simulate changes in river discharge while accounting for upstream water abstraction and returns. GHMs have been used to examine several nexus issues, including: (1) the implications of future sectoral water use demands for grid-based water scarcity [42,45-47]; (2) the implications of climate change for irrigation water demands [26,48]; (3) the impacts of water constraints on agricultural productivity [26,29]; and (4) the implications of climate-induced water constraints for the electricity sector [49].

Studies exploring the implications of socioeconomic and climatic change for future water scarcity indicate that increasing water demands associated with population and economic growth will have much larger impacts on water scarcity than climate change $[4,50,51]$. Thus, water scarcity projections are sensitive to the model assumptions that drive the evolution of sectoral water demands. These demands are estimated in GHMs primarily using current country-level statistics on water use intensity, 
which are combined with GDP and assumptions regarding future trends of technological (e.g., efficiency improvement) and structural (e.g., income effects on water use) change to estimate future intensities $[46,47,52]$. Scenario analysis is used to assess how changes in water use intensities across multiple sectors impact future water scarcity [42,47]. However, GHMs do not have a hydro-economic representation of the water supply system and thus can only simulate future water scarcity under exogenous assumptions concerning the major drivers, such as land under irrigation, irrigation type, reservoir size, and sectoral water use intensities. Moreover, there is significant variability in both river discharge and water demand estimates among GHMs, leading to substantial variation in scarcity estimates $[16,53,54]$. For example, in a middle-of-the road scenario where population reaches about 9 billion in 2050 (e.g., SSP2 or SRES B2), the population exposed to severe water scarcity in the 2050s (annual WSI $\geq 0.4$ ) ranges widely between 5.1 billion in WaterGAP [45] and 2.6-2.8 billion in H08 [42].

GHMs have also been used to assess trade-offs between the water and agricultural sectors by examining the implications of climate change for irrigation water requirements [48] and the impacts of water constraints for irrigation and agricultural productivity [26]. In most GHMs, agricultural water demand is derived endogenously as the difference between crop-specific potential evapotranspiration and the plant-available precipitation calculated in a rainfall-runoff module. GHMs tend to have less sophisticated representation of crop water requirements than GGCs, which include more crop types and better representation of $\mathrm{CO}_{2}$ fertilization and growing season adaptations. As a result, GHMs predict much larger increases in global irrigation water withdrawals in response to climate change than GGCs [26]. The ensemble mean across multiple emission pathways and GHMs is a $10 \%$ increase in the 2050s and a $14 \%$ increase in the 2080s [48]. When coupled with GGCs to compute productivity impacts, significant agricultural production losses are expected to occur when water for irrigation is constrained by other uses [26]. However, GHMs typically only consider renewable water available within each grid cell and thus ignore unconventional (e.g., fossil groundwater) and non-local water resources (e.g., interbasin transfers), which could help to mitigate the impacts of local water constraints.

GHMs have also been used to quantify water-related climate change impacts on the electricity sector $[49,55,56]$. These studies find that reduced river flows and increased river water temperatures could have large impacts on the operation and availability of existing hydroelectric and thermoelectric power plants, with the probability of extreme reductions in available plant capacity perhaps tripling with climate change [57]. In contrast, non-water dependent wind and solar photovoltaic technologies are more robust to water scarcity and thus policy that promotes a transition to these technologies could have the co-benefit of creating a less water-dependent power sector [58]. While adaptation strategies for improving power sector resilience, including switching to less water-intensive technologies (e.g., from coal to gas), shifting to less water-intensive cooling technologies (e.g., once-through to recirculating and dry cooling), and using alternative water sources (e.g., seawater) have been assessed using GHMs, these analyses are conducted using exogenously-defined scenarios. The scenarios feature impacts on existing power plants and are assessed given pre-specified adaptation strategies that are not necessarily feasible within the economic lifetime of existing power plants.

Historic and contemporary water scarcity assessments conducted across a range of spatial and temporal resolutions suggest that water scarcity increases substantially when evaluated at finer resolutions $[50,54,59,60]$. These findings highlight the local and seasonal nature of water constraints and the importance of modeling the water sector at fine spatial and temporal resolutions. However, it should be noted that substantial water demand in water-scarce regions within developed countries is served by major conveyance networks (e.g., the State Water Project in California [61]). Assessments with finer spatial resolution may overestimate water scarcity since such adaptation strategies are not included in GHMs [62]. Moreover, water withdrawals in several regions (Middle East, India, and China) are expected to exceed the water available from rivers, lakes, reservoirs, and renewable groundwater. This suggests that alternative water resources, such as nonrenewable groundwater, desalination, interbasin transfers, and wastewater, will be necessary $[63,64]$. However, these alternative water resources are rarely represented within GHMs as it is difficult to simulate the future deployment of these strategies 
without a hydro-economic module to evaluate their relative trade-offs [65]. Furthermore, although environmental flow requirements (EFR) are included in several GHMs, significant research is required to better understand EFRs in specific locations and their implications for water scarcity [37,66-69].

Currently, GHMs focus on the quantities of water demanded and available, but the impacts of industrial, domestic, and agricultural activities on water quality and the implications of diminished water quality for ecosystems and human consumption have only recently begun to be modeled at global scales [70-73]. Two examples include the outputs associated with the Global Nutrient Export from Watersheds (Global NEWS) project [74] and the WorldQual model, which is a global gridded water quality model that estimates loadings and in-stream concentrations of several water pollutants based on river conditions and return flows from WaterGAP [71,75]. Although, a few studies have examined future changes in nitrogen and phosphorus pollution based on exogenous scenarios of land use change and agricultural practices $[70,76]$, these models have not been linked to economic models to endogenously explore the trade-offs between agricultural intensification and water quality. Furthermore, more research is required to link basin and global water modeling [77], and to better estimate the locations of future sources of water pollution from the industrial, municipal, and agricultural sectors so to improve processed-based understanding between these sources and water quality. The hydrological modeling community has also recently assessed the capability for GHMs to reproduce satellite observed groundwater storage changes [78] and extreme flows [16], and are indicating improvement is needed to capture these important processes.

\section{Assessing Solutions for Mitigating and Adapting to Global Change}

The second group of models includes sectoral or multi-sectoral global economic models that are designed to investigate possible strategies for responding to future socioeconomic and climatic change. Outputs from GHMs and GGCs previously discussed are sometimes aggregated and soft-linked to economic models, used as inputs to provide physical resource constraints and supply and demand curves. However, the economic models add the important capability of evaluating economic trade-offs and synergies among multiple strategies for both mitigating environmental degradation and ensuring the provision of adequate and affordable food, energy, and water to meet future anthropogenic demands. Consequently, these models provide insights into possible regional and global solutions to nexus challenges and thus are useful for informing long-term policy and planning decisions. The inclusion of environmental objectives is particularly relevant to the identification of synergistic strategies for meeting multiple SDGs. The SDG targets seek not only to eradicate human poverty and hunger but also a range of other objectives, including the mitigation of climate change and biodiversity loss.

Both partial equilibrium (PE) and computable general equilibrium (CGE) models have been developed at the global-scale for exploring the response of supply systems to socioeconomic and climatic changes. PE models include: (1) agro-economic, models which are designed to identify land use, management, and demand responses in the agricultural and forestry sectors; (2) energy-economic models, which evaluate transformations of the energy sector; and (3) hydro-economic models, which evaluate management and demand responses in the water sector. Integrated nexus frameworks have also been developed for evaluating interactions among water, energy, and land management, either through the linkage of PE models or the extension of CGE models, which endogenously capture interactions among global economic sectors.

\subsection{Agro-Economic Models}

Agro-economic models are useful for exploring the interactions between water and land management as they quantify how future food, fiber, and bioenergy demands can be met under water, land, and climate constraints and economic impacts. The main response strategies that are evaluated by these models are spatial re-allocation of crops and livestock production to locations with higher productivity (including inter-regional trade), expansion of managed land, agricultural intensification, and demand response. Many agro-economic models are linked to global gridded 
crop models, which provide the potential yields, suitable areas, and fertilizer and irrigation water requirements for particular crops as inputs.

Global agro-economic models incorporating water constraints on agricultural production include GLOBIOM (GLObal BIOsphere Management model [36,79]; linked to EPIC and LPJmL), MAgPIE (Model of Agricultural Production and its Impact on the Environment [35,80]; linked to LPJmL), GCAM (Global Change Assessment Model [81,82], IMAGE (Integrated Model to Assess the Global Environment [83]; linked to MAGNET and LPJmL), and IMPACT-WATER (International Model for Policy Analysis of Agricultural Commodities and Trade [84,85]). Crop yields and irrigation are constrained by water availability within each agricultural production unit, which can be represented on a grid as small as 30-arcminutes. GLOBIOM and MAgPIE do not include explicitly a representation of water allocation between up and downstream spatial units. However, it should be noted that although MAgPIE, GLOBIOM and IMAGE make production decisions at high resolution, commodity demands, prices, and trade are calculated within coarser economic regions (up to 57 regions in GLOBIOM, 10 regions in MAgPIE, and 26 regions in IMAGE) (Figure 1). The fact that demands need only to be met by the aggregated regional production tends to concentrate agricultural expansion in the most profitable and productive areas, regardless of their proximity to demands [35]. Notable exceptions occur when internal transportation cost is used for the distance to internal markets such as in regional GLOBIOM implementations [86]. This assumption may be appropriate in developed regions with sophisticated food distribution infrastructure, but may misrepresent cropland expansion and overestimate the potential for adaptation in developing regions with poor infrastructure and a reliance on subsistence farming [87].

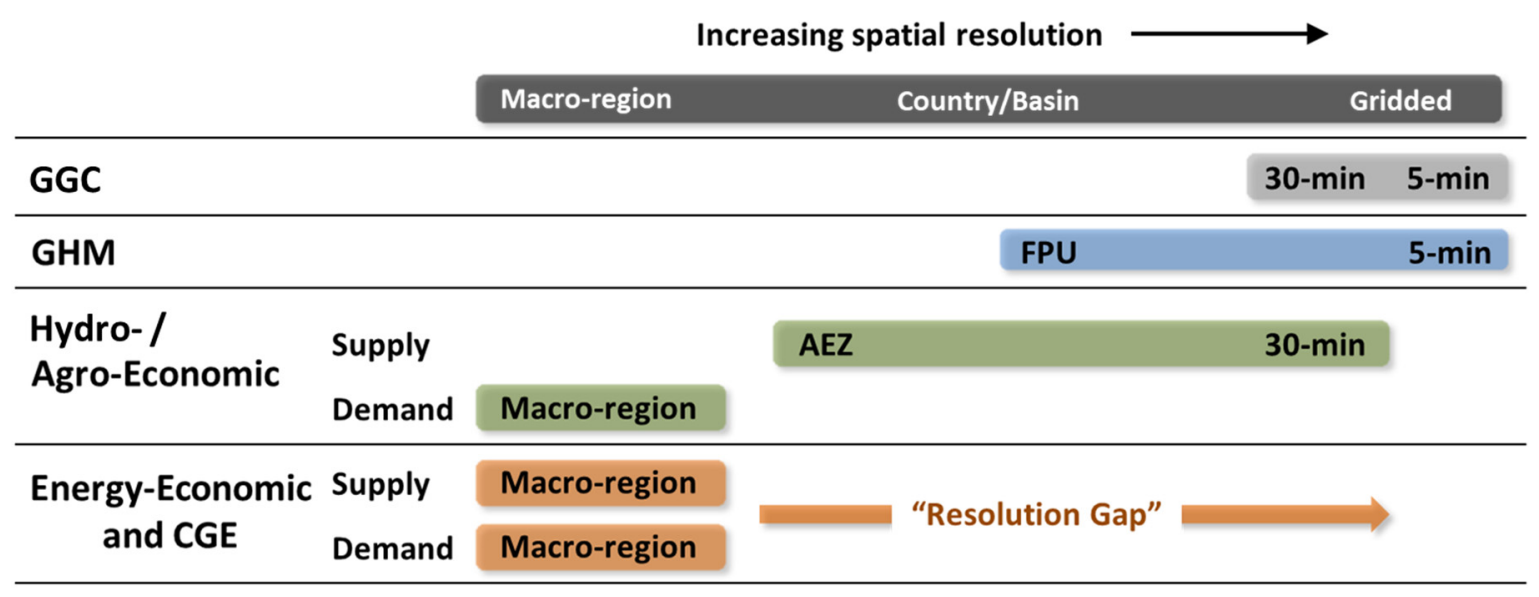

Figure 1. Range of spatial resolutions over which widely used global gridded crop models (GGCs,) GHMs, and economic models operate. Note that the resolution of supply decisions and commodity demands can differ within economic models. 30-min $=30$-arcminutes, which is equivalent to 0.5 degrees; 5 - $\min =5$-arcminutes, which is equivalent to 0.083 degrees; FPU $=$ food production unit; $\mathrm{AEZ}=$ agro-ecological zone; $\mathrm{CGE}=$ computable general equilibrium.

In terms of land use conversion, most global agro-economic models project a $20-25 \%$ increase of cropland by 2050 relative to 2005 when climate change is not considered [88]. Most of the expansion occurs in South America and sub-Saharan Africa. However, the results across models are quite diverse as a result of differences in the potential for endogenous productivity responses, availability of cropland, and the ease of land conversion and trade (see [88] and [89] for descriptions of model differences). Further research is needed to resolve some of the underlying uncertainties that drive these model differences. Furthermore, developments are needed to improve the representation of localized water constraints, governance, and the heterogeneity of both agricultural producers and consumers in order to better account for financial and institutional constraints on adaptation [87]. Finally, most global agro-economic models do not track the energy requirements associated with agricultural production, 
which will be necessary for examining the land-energy nexus including the response of farmers to varying energy prices [90].

Global agro-economic models have been applied to examine several nexus challenges, including: (1) the role of trade in reducing regional water scarcity [91-93]; (2) the potential for reduced consumption of livestock products and reduced food waste to decrease irrigation water requirements [79,92,94]; (3) the implications of bioenergy expansion for irrigation water requirements, land use, and terrestrial ecosystem impacts [36,95-99]; and (4) the implications of environmental flow requirements (EFRs) for food production $[28,68]$. Within AgMIP, harmonized scenarios were conducted with several global agro-economic models to examine robust solutions for meeting future food demand under climatic and socioeconomic change $[89,100,101]$. The resulting studies explore the roles of trade [102] land use conversion [88], and land intensification in meeting future demands for major crops (wheat, rice, soybeans, and grains) [100].

Although climate change under a high GHG emissions scenario (RCP 8.5) is expected to reduce global yields of major crops by an average of $17 \%$ by 2050 , economic responses, such as cropland expansion and intensification, can greatly reduce productivity impacts [100]. However, intensification may exacerbate other environmental challenges, such as non- $\mathrm{CO}_{2}$ GHG emissions and water scarcity if irrigation and fertilizer use are expanded [97,99,103,104]. Studies using GLOBIOM and MAgPIE confirm the value of response strategies, but indicate a much stronger role for trade in compensating for productivity losses and regional water scarcity since food production can be shifted to regions with more abundant water and better growing conditions [91-93,105]. The importance of trade highlights the need for models with a global scope as they can explicitly account for the disparate growing conditions among regions and deploy trade when economically favorable. Reduced consumption of livestock-based products (e.g., meat, eggs, and milk) and reduced food waste have also been demonstrated as effective strategies for alleviating future agricultural land and water requirements, especially in conjunction with liberalized trade $[79,92,94]$. There are also the impacts of higher $\mathrm{CO}_{2}$ concentrations on the quality of the nutrients in food [106], indicating a need to link food impacts and mitigation strategies at the global-scale.

The introduction of climate policy is expected to alter global land use patterns as land-based mitigation strategies, such as bioenergy cultivation and conservation/expansion of forests, will change the relative value of land uses [3]. The negative effects of stringent land-based climate mitigation on global hunger and food consumption was shown in one recent study to be greater than the equivalent impacts of climate change [107]. Global models agree that targeted policies can help avoid tradeoffs with food pricing [9]. Of particular relevance to the nexus is the deployment of bioenergy since its cultivation may have significant implications for both land and water resources, particularly when coupled with CCS to achieve negative emissions $[108,109]$. Several studies examine the implications of bioenergy expansion by introducing the bioenergy demands projected by energy-economic models into agro-economic models to assess land use change under land and water constraints $[36,95,97,99]$. Agro-economic models have also been applied to explore the deforestation implications of biofuel expansion across a range of bioenergy conversion pathways as well as the required adaptation responses to support bioenergy expansion under forest protection policies [35,96-98]. These studies suggest that large-scale bioenergy expansion consistent with limiting global mean temperature change to $2^{\circ} \mathrm{C}$ above pre-industrial levels could roughly double agricultural water requirements by the end of the century $[99,110,111]$. Moreover, the land required for this expansion would result in extensive conversion of forest and pasture and land conversion could increase by $41 \%$ if irrigation of bioenergy crops is prohibited [99]. These findings suggest that large-scale bioenergy deployment could be counterproductive for land-based GHG emissions, terrestrial ecosystems, and water stress.

EFRs have only recently begun to be incorporated into global agro-economic models to explore the response of the agricultural sector to reduced water availability stemming from environmental considerations $[28,68]$. These studies find that the introduction of EFRs substantially reduces agricultural water withdrawals and irrigated cropland globally, but that food demands can still be met through 
cropland expansion, intensification, and increased trade [68]. While this finding implies that trade-offs may exist between aquatic and terrestrial ecosystem protection, increased food demand due to socioeconomic change requires 5-9 times more conversion of unmanaged land than EFRs, suggesting that EFRs have only a moderate impact on terrestrial ecosystems at the global scale [28].

Finally, while agro-economic models have been successful in quantifying the implications of food and bioenergy expansion for the magnitude, or quantity, of land use change (e.g., deforestation), they have yet to relate the impacts of the resulting land use change and specific management practices to ecosystem quality [112]. This is particularly true for land management practices that do not alter the land cover classification, but may still degrade terrestrial ecosystems, such as the use of forest residues for bioenergy. Consequently, next-generation models are needed that spatially disaggregate changes in land use and management practices and relate these changes using empirical studies to the health and biodiversity of specific ecosystems. The Global Biodiversity Model (GLOBIO) is an example of an attempt to address this shortcoming by relating human-induced land use pressures to biodiversity loss at the global scale [113]. Although GLOBIO presents a novel methodology for linking land use pressures to biodiversity loss, the value of the findings is inherently constrained by limitations at the global scale associated with: (1) modeling environmental drivers of biodiversity loss; (2) disaggregating land use change across ecosystems; and (3) establishing robust relationships between environmental drivers and biodiversity loss for broad land use categories. Thus, there is significant scope for improving the representation of how land conversion and management decisions impact terrestrial ecosystem quality, diversity, and function.

\subsection{Energy-Economic Models}

The energy sector accounts for approximately $15 \%$ of global total water withdrawals with the majority withdrawn for the cooling of thermoelectric power plants [114]. Meanwhile, in the "middle-of-the-road" shared socioeconomic pathway (SSP2), global electricity generation is expected to triple from 2005 to 2050 and increase more than six-fold in Africa and Asia, according to the average of six global energy-economic models [115]. Thus, without changes in the water-use intensity of electricity generation, it is expected that the share of energy sector water use will increase, especially in developing countries. Strategies for reducing energy-related water use include shifting to more water-efficient cooling technologies (e.g., recirculating and dry cooling), using alternative water resources (e.g., wastewater or seawater), constructing less water-intensive energy transformation technologies (e.g., gas instead of coal; wind and solar PV), and using distribution infrastructure (e.g., transmission lines) to import energy from other, possibly more water-abundant, regions. However, adapting to water scarcity is expected to increase energy prices and may significantly alter future energy transitions $[13,116]$. Meanwhile, regional studies suggest that the adoption of energy-intensive water supply technologies, such as water conveyance and desalination, could substantially increase energy demands and the cost of water supply while exacerbating the climate change mitigation challenges already faced by the energy sector in water-scarce regions $[13,117]$. Thus, it is important that energy-economic models improve their representation of water-energy trade-offs in assessing energy transition pathways.

However, global energy-economic models typically operate at a coarse spatial scale with energy production and demand represented within macro-regions (Figure 1). Thus, it is challenging to incorporate meaningful water constraints, as there is typically sufficient water when assessed at the macro-regional scale, even though constraints might occur in reality at the asset-scale. As a first step, several global energy-economic models have begun to track the water consumption and withdrawal of the electricity sector and entire energy sector as a post-processing exercise $[58,111,118]$. These studies apply exogenous assumptions about cooling technology transitions to pre-existing energy system transformation pathways and thus do not explore how mitigation pathways respond to water scarcity. In scenarios where cooling technologies are fixed at present shares, the studies indicate that water withdrawals are expected to increase between $0 \%$ and $150 \%$ over the 21 st century, depending on the future electricity generation portfolio $[58,111,119]$. 
Both global and regional assessments generally suggest that increasing energy demands and electrification will likely lead to growing energy-related water consumption $[58,111,119]$. Global mitigation pathways that rely more heavily on wind and solar PV technologies are expected to consume less water than pathways that rely on hydropower or low-carbon thermal power technologies that require water for cooling, such as nuclear, concentrating solar power (CSP), and fossil technologies with carbon capture and storage (CCS) [58,111,119]. Moreover, the adoption of air and seawater cooling can help to maintain greater mitigation flexibility by reducing the water consumption of thermal power generation.

More recently, the economic impacts of cooling system choices were incorporated into a global energy-economic model to study the interactions between the SDG for clean water (SDG6) and the Paris Agreement $1.5^{\circ} \mathrm{C}$ target [13]. The results indicate that combined policies drive power systems towards water-efficient low-carbon generation technologies (e.g., wind and solar) faster than if each policy was applied on its own. This is because wind and solar are usually expanded more aggressively later in the 21st century in future $1.5^{\circ} \mathrm{C}$ pathways simulated with global energy-economic models. However, when the climate policy is layered with the SDG6 water efficiency policy, it is better to expand wind and solar systems before 2030 to reduce energy sector water use in the SDG timeline. Less water-efficient power generation choices pose the risk of stranded assets after 2030 due to potential water efficiency standards driven by the SDGs.

Technologies that convert biomass to transportation fuels, electricity, and heat are also widely deployed in energy-economic models to mitigate climate change, especially when coupled with CCS to achieve negative emissions $[107,108]$. The cultivation of biomass requires both land and water resources, but these nexus trade-offs are underrepresented in global energy-economic models. Regional biomass potentials are typically represented by exogenously-derived supply curves that are not accounting for dynamic water and land trade-offs associated with their exploitation. However, several studies have recently coupled agro- and energy-economic models in an effort to better account for the emissions, land use, and water trade-offs $[3,13,82,120]$. Studies using these frameworks suggest that water constraints are expected to increase development costs in some regions due to water stress $[99,110,111,121,122]$.

Energy- and hydro-economic models need to be coupled over multiple decision scales to reflect the complex interactions between systems at different locations. An additional benefit of linking hydro and energy-economic models is the ability to represent innovative technologies at the interface between the two sectors. For example, the application of combined heat and power (CHP) to reduce cooling loads by providing waste heat to nearby industries (including to support desalination [123]), the recovery of energy, fertilizer, and even nutrient recovery from wastewater [124], and the use of treated wastewater as cooling water for thermoelectric power plants [125]. Finally, terrestrial ecosystems are not only affected by food, fiber, and bioenergy production, but also from land conversion and air pollution associated with energy supply systems. Examples include ecosystem destruction associated with coal mining (e.g., open pit and mountaintop removal) and flooding for hydroelectric reservoirs as well as ecosystem degradation from acid rain associated with coal-based power plants [126-129]. Spatially-explicit energy-economic models would improve the assessment of such localized ecosystem impacts.

\subsection{Hydro-Economic Models}

A global hydro-economic model would track the transformation and delivery of different water resources (e.g., untreated freshwater, treated freshwater, groundwater, and seawater) via a portfolio of supply technologies (e.g., water treatment, conveyance infrastructure, and desalination). Moreover, explicit representation of water conveyance infrastructure is needed to assess the option of redistributing water resources, especially in the context of cities [62]. Hydro-economic models exist for these purposes, but have mainly been applied at the regional scale [130-132]. The IMPACT-WATER model is a global hydro-economic framework, which explicitly accounts for water routing among river basins as well as water storage associated with existing reservoirs [133]. The model framework also simulates crop production but does not assess linkages with energy system transformation. The Extended 
Continental-scale Hydroeconomic Optimization model (ECHO) represents an important contribution because it has sub-river basin-scale resolution while covering all of Africa and decisions in water, electricity and irrigation systems [134]. However, there is no representation of land-use change and transformation of the energy supply is not explicitly linked across the continental study region.

\subsection{Global Integrated Nexus Solution Frameworks}

Global integrated nexus solution frameworks bridge the gap across all three resources and have been developed by the coupling and extension of existing global models. Frameworks are including transformational changes in the WEL resource supply-chain based on economic decision-criteria, and are generally classified as either partial equilibrium (PE) or computable general equilibrium (CGE) type models. CGE-based frameworks have been developed to improve the representation of the land and water impacts associated with bioenergy deployment and to capture the trade-offs between land-based and energy-based mitigation strategies. In contrast to PE models, which include representation of a limited number of economic sectors (e.g., agriculture, livestock, and forestry in agro-economic PE models), CGE models include representation of all global economic sectors and thus can provide insight into the macro-economic implications of future policy and resource developments. Many global nexus solution frameworks exist including GCAM [81]; AIM/CGE (Asia Pacific Integrated Model/Computable General Equilibrium; $[135,136])$, GTAP-BIO-W (Global Trade Analysis Project model with Biofuels and Water; [137]), IGSM-WRS (Integrated Global System Model-Water Resource System; [138]), ANEMI [139]; and MuSIASEM (Multi-scale integrated analysis of societal and ecosystem metabolism; [140]).

While global PE models include very detailed representations of the commodities, demands, and transformation technologies in their respective sectors, global CGE models tend to be less resolved. However, sectoral detail in CGEs is often tailored for answering specific research questions. For example, GTAP-BIO-W is an extension of the single-period GTAP model [141] in which biofuel production and irrigated agriculture have been disaggregated and irrigation water has been added as a production input for which crops compete at the scale of major river basins [137]. Studies using GTAP-BIO-W have applied exogenous assumptions regarding future biofuel expansion and irrigation water availability to examine how these future conditions/shocks impact global welfare loss, land use change, and indirect land use change (ILUC) emissions [142,143]. However, GTAP-BIO-W has limited representation of energy and water supply technologies that could help to mitigate water constraints (e.g., interbasin transfers) and/or bioenergy-induced land use change (e.g., alternative low-carbon transport fuels). Thus, the evaluation of nexus trade-offs is hampered by the limited representation of technological solutions. Moreover, as a single-period model, it is not designed to identify long-term transition pathways for adapting to and mitigating global socioeconomic and climatic changes.

In contrast, EPPA (Emissions Prediction and Policy Analysis; [144,145]), which is the CGE model used in the IGSM-WRS framework, and AIM/CGE are recursive dynamic models that are explicitly designed to evaluate long-term transition pathways [146,147]. To account for trade-offs among energyand land-based mitigation strategies, both models include disaggregated representations of energy production technologies and distinguish the agriculture, livestock, and forestry sectors $[145,148,149]$. AIM/CGE also disaggregates several agricultural crops and energy end-use technologies. In addition, both models have been coupled to biophysical land use models to exploit spatially-explicit information on land productivity and to downscale the macro-regional land demands determined by the CGE models $[150,151]$. Downscaled land use allocation is important for capturing the spatial distribution of carbon stock density and tends to indicate larger ILUC emissions associated with bioenergy expansion than macro-regional estimates [142,151]. Yet, land allocation is driven primarily by biophysical conditions (e.g., land productivity) and does not consider other pertinent factors (e.g., infrastructure and institutions).

Although land-energy trade-offs are well-represented through endogenous competition among food production, bioenergy cultivation, and afforestation $[149,150]$, water linkages are less developed 
and the implications of water constraints for energy and agricultural decisions have not been fully explored. Like the energy-economic PE models, AIM/CGE has quantified industrial water withdrawals as a post-processing exercise in which energy-related water use is a function of the future energy technology portfolio [135]. In contrast, in the IGSM-WRS framework, EPPA generates scenario-based GDP and population projections, which are used by the water resource model to determine future municipal and industrial water demands [138,152]. Thus, future energy-related water use is not explicitly tied to the portfolio of technologies deployed, but rather driven by GDP and population projections.

The IGSM-WRS framework includes a linkage with the MIT Earth System Model (MESM), which projects changes in temperature, precipitation, and runoff. A unique feature of the IGSM-WRS is its incorporation of the water module of the IMPACT-WATER model, which explicitly accounts for water routing among river basins as well as water storage associated with existing reservoirs. Thus, given changes in anthropogenic water demands and natural runoff, IGSM-WRS can assess future water stress globally. However, the link between EPPA/MESM and the water resource model is unidirectional meaning that water constraints do not influence agricultural and energy supply decisions. Moreover, the water management module only considers the existing built environment (e.g., reservoirs) and thus does not assess adaptation responses to water scarcity. Finally, while CGE models often include modules to downscale model outputs (e.g., water and land demands), all decisions and trade-offs are assessed at the macro-regional scale, as seen in Figure 1.

Global nexus assessment frameworks have also been developed by coupling agro- and energy-economic PE models to examine cross-sectoral climate change mitigation strategies across a range of socioeconomic scenarios. Whereas, the dynamics of the energy- and agro-economic systems are fully coupled in GCAM, agro-economic trade-offs, such as land-based emissions, deforestation, and water use, are emulated through bioenergy supply curves in the energy modules of IMAGE, REMIND-MAgPIE, and MESSAGE-GLOBIOM [3,82,83,153]. Along with AIM/CGE, these PE models have been used to quantify uncertainties across the SSP marker scenarios [15]. Multi-model analysis provides a framework for assessing the scale of the uncertainties and to identify robust trends across different modeling assumptions. The multi-model results have also provided the basis for global pathways communicated in recent reports by the Intergovernmental Panel on Climate Change, which are informing policy-makers of impacts, uncertainties and required actions and solutions [154,155]. Table 1 highlights the strengths and weaknesses of the SSP scenario modeling frameworks in terms of their assessed ability to incorporate nexus trade-offs. The main weaknesses of the models can be attributed to: (1) high data and computational requirements; (2) inconsistent spatial and temporal definitions across the models and the historical datasets used for calibration; and (3) diversity in the representation of future technology and policy solutions over a multi-decadal simulation period.

The multi-model analysis of the SSPs revealed important WEL resource trends under future policies. In a stringent climate change mitigation scenario (RCP2.6), cropland is expected to increase across all SSPs because of the expansion of bioenergy cultivation [3]. Taking the average across models for each SSP, cropland increases 5-53\% between 2005 and 2100. Moreover, climate change mitigation incentivizes the conservation/expansion of forests, which increase on average 3-16\% globally. The increase in both cropland and forest is achieved through the reduction of pasture (6-20\% loss) and other natural land (1-18\% loss), which includes unmanaged grassland and savannah. Thus, reduced impacts on forest ecosystems may come at the expense of impacts to other terrestrial ecosystems. To improve the protection of both forest and non-forest ecosystems, a universal carbon price that applies uniformly to all sectors, including land use change and other terrestrial emissions can promote the most cost-effective land-based mitigation $[80,150,156]$. While bioenergy expansion puts additional pressure on natural land by increasing the land required for crops, differences in deforestation trends across the models are driven primarily by the availability of land-based mitigation options that increase forested land, such as afforestation and reforestation $[3,20]$. Variation in the land use implications associated with bioenergy expansion is also driven by differences in the structural features and assumptions of 
the models and, particularly, how they represent land conversion, yield improvements, food demand elasticity, trade, and bioenergy feedstocks [95].

Although the land-energy and land-water linkages have been improved in many models, including IMAGE and AIM/CGE $[149,157]$, there has been less progress in capturing the linkages between the water and energy supply sectors. For example, in these frameworks, energy supply decisions (e.g, cooling technology choice) and energy sector water use are not responsive to water constraints. Rather, energy sector water use is provided as an exogenous water demand that impacts the water available for irrigation. GCAM and MESSAGE-GLOBIOM have added the capability to assess the endogenous responses of the agricultural, energy, and water sectors to water scarcity by adding water constraints at the scale of major global river basins $[13,82,122]$. Initial applications of these integrated models indicate that water withdrawals are reduced when water constraints are included. This is because sectors are incentivized to reduce water demand through various response strategies. In GCAM, the agricultural sector exhibits a large response with a $20 \%$ reduction in withdrawals by the end of the century. Water constraints have a smaller impact on the energy sector with a transition to less water-intensive production and cooling technologies.

Although the inclusion of water constraints and the simultaneous assessment of solutions across land, energy, and water represent a significant step forward, there are opportunities for improvement. First, many response options for addressing water scarcity are not explicitly included. For example, a portfolio of efficient irrigation technologies, interbasin transfer options, and expansion of water storage can provide flexibility in meeting water supply targets. Finally, global frameworks are operating with annual resolution and thus do not explicitly account for the seasonal and intra-annual variability of water supply and use. Instead, the frameworks are introducing the concept of accessible water, which in GCAM is a function of baseflow and storage in existing reservoirs [82]. 
Table 1. Representation of nexus linkages within the five global economic models that were used to quantify the Shared Socioeconomic (SSP) marker scenarios [15]. $(+)$ indicates aspects of each linkage that are represented in the model; (-) indicates aspects that are missing or poorly represented.

\begin{tabular}{|c|c|c|c|c|c|c|}
\hline Model & References & Water-Energy & Land-Energy & Water-Land & Ecosystem Impacts & Other Linked Models \\
\hline GCAM & $\begin{array}{c}{[63,82,122,156,} \\
158,159]\end{array}$ & $\begin{array}{l}\text { (+) Tracking of water } \\
\text { demands for irrigated } \\
\text { bioenergy and electric } \\
\text { power generation with } \\
\text { alternative cooling } \\
\text { technology options } \\
\text { (+) Simplified } \\
\text { representations of water } \\
\text { demands for energy } \\
\text { industries (e.g., water } \\
\text { demands for primary } \\
\text { energy production } \\
\text { (mining and drilling) } \\
\text { scale with production) } \\
(-) \text { Energy demand } \\
\text { associated with water } \\
\text { sourcing, delivery and } \\
\text { treatment is not included } \\
\text { (-) Water demands for } \\
\text { transport fuel production } \\
\text { not included } \\
(-) \text { Coarse resolution of } \\
\text { the energy sector } \\
\text { impedes representation } \\
\text { of localized water } \\
\text { constraints }\end{array}$ & $\begin{array}{l}\text { (+) Land-use and energy } \\
\text { modules are fully } \\
\text { coupled so that bioenergy } \\
\text { competes directly with } \\
\text { other land-based } \\
\text { mitigation strategies } \\
\text { (+) Biomass options } \\
\text { include non-woody } \\
\text { bioenergy crops, } \\
\text { traditional biomass, and } \\
\text { short-rotation tree } \\
\text { plantations } \\
\text { (+) Land allocation for } \\
\text { biomass production } \\
\text { competes with land for } \\
\text { other purposes. } \\
\text { (+) AFOLU emissions } \\
\text { and sinks are represented } \\
\text { with endogenous } \\
\text { trade-offs between energy } \\
\text { and land-based } \\
\text { mitigation } \\
\text { (-) Biomass from forest } \\
\text { residues and managed } \\
\text { natural forests not } \\
\text { represented (except } \\
\text { traditional biomass) } \\
\text { (-) Land requirements of } \\
\text { energy sector besides } \\
\text { biomass not included } \\
\text { (-) No energy price } \\
\text { feedbacks on land use } \\
\text { decisions }\end{array}$ & $\begin{array}{l}\text { (+) Water demands for all } \\
\text { major crop types are } \\
\text { estimated in each AEZ } \\
\text { and region } \\
\text { (+) Availability of water } \\
\text { at basin-scale affects } \\
\text { irrigated land allocation } \\
\text { (+) Agricultural trade } \\
\text { affects regional water use } \\
\text { and land allocation } \\
\text { (+) Non-renewable } \\
\text { groundwater explicitly } \\
\text { modeled } \\
\text { (-) Relatively coarse } \\
\text { resolution (235 river } \\
\text { basins) } \\
\text { (-) Future infrastructure } \\
\text { assumptions (irrigation } \\
\text { efficiency, reservoir } \\
\text { storage) are exogenous }\end{array}$ & $\begin{array}{l}\text { (+) Environmental flow } \\
\text { requirements (EFRs) are } \\
\text { represented at basin-scale } \\
\text { (+) Implications of land } \\
\text { pressures for loss of } \\
\text { forests and other } \\
\text { unmanaged land } \\
\text { (-) Implications of future } \\
\text { resource management for } \\
\text { terrestrial/aquatic } \\
\text { ecosystem quality not } \\
\text { explicitly modeled }\end{array}$ & $\begin{array}{l}\text { (+) Downscaled water } \\
\text { demands from GCAM } \\
\text { have been soft-linked } \\
\text { with fine resolution } \\
\text { models of runoff, river } \\
\text { routing, and water } \\
\text { management to assess } \\
\text { water scarcity } \\
\text { (+) GCAM has been } \\
\text { soft-linked with an } \\
\text { electricity operation } \\
\text { model (PROMOD) to } \\
\text { assess electricity grid } \\
\text { resilience to } \\
\text { hydro-climatological } \\
\text { change } \\
\text { (+) GCAM has been } \\
\text { hard-linked to the } \\
\text { Community Earth System } \\
\text { Model (CESM) to } \\
\text { construct the integrated } \\
\text { Earth system model } \\
\text { (iESM) to assess the } \\
\text { coupled human-climate } \\
\text { system. }\end{array}$ \\
\hline
\end{tabular}


Table 1. Cont.

\begin{tabular}{|c|c|c|c|c|c|c|}
\hline Model & References & Water-Energy & Land-Energy & Water-Land & Ecosystem Impacts & Other Linked Models \\
\hline IMAGE & {$[11,46,83,113]$} & $\begin{array}{l}(+) \text { Tracking of water } \\
\text { demands for irrigated } \\
\text { bioenergy and electric } \\
\text { power generation with } \\
\text { alternative cooling } \\
\text { technology options } \\
(+) \text { Hydropower potential } \\
\text { based on the hydrological } \\
\text { module of LPJmL } \\
(-) \text { Energy demand } \\
\text { associated with water } \\
\text { sourcing, delivery and } \\
\text { treatment is not included } \\
(-) \text { Water demands for } \\
\text { energy extraction and } \\
\text { transport fuel production } \\
\text { not included } \\
\text { (-) Coarse resolution of } \\
\text { the energy sector } \\
\text { impedes representation } \\
\text { of localized water } \\
\text { constraints }\end{array}$ & $\begin{array}{l}\text { (+) Land-use and energy } \\
\text { models are soft-linked to } \\
\text { ensure that biomass cultivation } \\
\text { costs are considered in energy } \\
\text { sector (bioenergy supply } \\
\text { curves are provided to energy } \\
\text { model and bioenergy demands } \\
\text { are fed back to land-use } \\
\text { models; no iteration) } \\
\text { (+) Biomass options include } \\
\text { non-woody bioenergy crops, } \\
\text { traditional biomass, and } \\
\text { short-rotation tree plantations } \\
\text { (-) Biomass from forest residues } \\
\text { and managed natural forests } \\
\text { not represented (except } \\
\text { traditional biomass) } \\
\text { (-) Land requirements of } \\
\text { energy sector besides biomass } \\
\text { not included } \\
\text { (-) In most applications, } \\
\text { sustainability criteria prohibit } \\
\text { biomass cultivation on land } \\
\text { needed for food production } \\
\text { (i.e., food first policy) } \\
\text { (-) AFOLU emissions and sinks } \\
\text { are tracked, but mitigation } \\
\text { trade-offs between bioenergy } \\
\text { and other land uses not } \\
\text { considered jointly } \\
\text { (-) No energy price feedbacks } \\
\text { on land use decisions }\end{array}$ & $\begin{array}{l}\text { (+) Water demands for all } \\
\text { major crop types are } \\
\text { estimated on } 0.5^{\circ} \text { grid } \\
(+) \text { Availability of water } \\
\text { at grid-scale affects crop } \\
\text { yields and thus land } \\
\text { allocation } \\
\text { (+) Agricultural trade } \\
\text { affects regional water use } \\
\text { and land allocation } \\
\text { (-) Future infrastructure } \\
\text { assumptions (irrigated } \\
\text { area and efficiency) are } \\
\text { exogenous } \\
(-) \text { No direct competition } \\
\text { for water among sectors } \\
\text { (-): Blue water availability } \\
\text { does not include } \\
\text { non-renewable } \\
\text { groundwater }\end{array}$ & $\begin{array}{l}\text { (+) Implications of land } \\
\text { pressures for risks of } \\
\text { erosion and soil } \\
\text { degradation, and loss of } \\
\text { forests and other } \\
\text { unmanaged land } \\
\text { (+) Biodiversity impacts } \\
\text { can be explored with } \\
\text { linkage to GLOBIO } \\
\text { (-) GLOBIO biodiversity } \\
\text { impacts tracked ex-post, } \\
\text { but do not constrain } \\
\text { supply decisions }\end{array}$ & $\begin{array}{l}\text { (+) LPJml provides crop } \\
\text { yields, irrigation water } \\
\text { requirements, and water } \\
\text { availability as inputs to } \\
\text { IMAGE } \\
\text { (+) Outputs from IMAGE } \\
\text { are used by GLOBIO to } \\
\text { examine biodiversity } \\
\text { impacts } \\
\text { (+) Downscaled } \\
\text { electricity production has } \\
\text { been provided as inputs } \\
\text { to WaterGAP to estimate } \\
\text { energy-related water } \\
\text { demands }\end{array}$ \\
\hline
\end{tabular}


Table 1. Cont.

\begin{tabular}{|c|c|c|c|c|c|c|}
\hline Model & References & Water-Energy & Land-Energy & Water-Land & Ecosystem Impacts & Other Linked Models \\
\hline $\begin{array}{l}\text { MESSAGE- } \\
\text { GLOBIOM }\end{array}$ & {$[13,36,153]$} & $\begin{array}{l}(+) \text { Tracking of water } \\
\text { demands for energy } \\
\text { extraction, transport fuel } \\
\text { production, and electric } \\
\text { power generation with } \\
\text { alternative cooling } \\
\text { technology options } \\
(+) \text { Energy demand } \\
\text { associated with water } \\
\text { sourcing, delivery and } \\
\text { treatment is included } \\
(-) \text { Coarse resolution of } \\
\text { the energy sector } \\
\text { impedes representation } \\
\text { of localized water } \\
\text { constraints }\end{array}$ & $\begin{array}{l}\text { (+) Land-use and energy } \\
\text { models are soft-linked to } \\
\text { capture mitigation trade-offs } \\
\text { between energy and land } \\
\text { sectors (biomass supply } \\
\text { functions and AFOLU } \\
\text { marginal abatement cost } \\
\text { curves at different bioenergy } \\
\text { and carbon prices are provided } \\
\text { to the energy model; carbon } \\
\text { prices and bioenergy demand } \\
\text { are fed back to the land-use } \\
\text { model; no iteration) } \\
\text { (+) Biomass options include } \\
\text { non-woody bioenergy crops, } \\
\text { traditional biomass, } \\
\text { short-rotation tree plantations, } \\
\text { forest residues, and wood and } \\
\text { by-products from forestry } \\
\text { (+) Land allocation for biomass } \\
\text { production competes with land } \\
\text { for other purposes, but } \\
\text { biomass demands come from } \\
\text { energy model } \\
\text { (+) AFOLU emissions and } \\
\text { sinks are represented with } \\
\text { trade-offs between energy and } \\
\text { land-based mitigation } \\
\text { emulated via soft-link } \\
\text { (-) Land requirements of } \\
\text { energy sector besides biomass } \\
\text { not included } \\
\text { (-) No energy price feedbacks } \\
\text { on land use decisions }\end{array}$ & $\begin{array}{l}(+) \text { Water demands for all } \\
\text { major crop types are } \\
\text { estimated on } 0.5^{\circ} \text { grid } \\
(+) \text { Availability of water } \\
\text { at grid-scale affects crop } \\
\text { yields and thus land } \\
\text { allocation } \\
(+) \text { Agricultural trade } \\
\text { affects regional water use } \\
\text { and land allocation } \\
(+) \text { : Irrigated area and } \\
\text { irrigation technologies } \\
\text { are endogenously } \\
\text { determined } \\
(+) \text { Competition for water } \\
\text { among sectors }\end{array}$ & $\begin{array}{l}\text { (+) Environmental flow } \\
\text { requirements are } \\
\text { represented } \\
\text { (+) Tracking of thermal } \\
\text { pollution from electricity } \\
\text { generation } \\
\text { (+) Implications of land } \\
\text { pressures for loss of } \\
\text { forests and other } \\
\text { unmanaged land } \\
\text { (-) Implications of future } \\
\text { resource management for } \\
\text { terrestrial/aquatic } \\
\text { ecosystem quality not } \\
\text { explicitly modeled }\end{array}$ & $\begin{array}{l}\text { (+) EPIC provides } \\
\text { spatially-explicit crop } \\
\text { yields and irrigation } \\
\text { water requirements, as } \\
\text { well as environmental } \\
\text { parameters related to } \\
\text { carbon, nitrogen, and } \\
\text { water cycling, to } \\
\text { GLOBIOM for several } \\
\text { land management } \\
\text { systems } \\
\text { (+) LPJml provides water } \\
\text { availability and } \\
\text { non-agricultural water } \\
\text { demands to GLOBIOM } \\
\text { (+) RUMINANT provides } \\
\text { biophysically consistent } \\
\text { information to GLOBIOM } \\
\text { about feed requirements, } \\
\text { livestock sector outputs, } \\
\text { and related non-CO } \\
\text { emissions }\end{array}$ \\
\hline
\end{tabular}


Table 1. Cont.

\begin{tabular}{|c|c|c|c|c|c|c|}
\hline Model & References & Water-Energy & Land-Energy & Water-Land & Ecosystem Impacts & Other Linked Models \\
\hline $\begin{array}{l}\text { REMIND- } \\
\text { MAgPIE }\end{array}$ & {$[2,3,96,111]$} & $\begin{array}{l}\text { (+): Tracking of water } \\
\text { demands for electric } \\
\text { power generation with } \\
\text { alternative cooling } \\
\text { technology options } \\
\text { (-): Energy demand } \\
\text { associated with water } \\
\text { sourcing, delivery and } \\
\text { treatment is not included } \\
\text { (-) Coarse resolution of } \\
\text { the energy sector } \\
\text { impedes representation } \\
\text { of localized water } \\
\text { constraints }\end{array}$ & $\begin{array}{l}\text { (+): Land-use and energy } \\
\text { models are soft-linked to } \\
\text { capture mitigation potentials in } \\
\text { the land sector (biomass supply } \\
\text { curves and AFOLU emissions } \\
\text { provided to energy model; } \\
\text { GHG prices and bioenergy } \\
\text { demand fed back to } \\
\text { agro-economic model; models } \\
\text { iterate until bioenergy and } \\
\text { emissions markets equilibrate) } \\
\text { (+) Biomass options include } \\
\text { non-woody bioenergy crops, } \\
\text { traditional biomass, and } \\
\text { short-rotation tree plantations } \\
\text { (+) Land allocation for biomass } \\
\text { production competes with land } \\
\text { for other purposes, including } \\
\text { food and mitigation } \\
\text { (+): AFOLU emissions and } \\
\text { sinks are represented with } \\
\text { trade-offs between energy and } \\
\text { land-based mitigation } \\
\text { emulated via soft-link } \\
\text { (-) Land requirements of } \\
\text { energy sector besides biomass } \\
\text { not included } \\
\text { (-): Biomass from managed } \\
\text { natural forests not represented } \\
\text { (except traditional biomass) } \\
\text { (-): No energy price feedbacks } \\
\text { on land use decisions }\end{array}$ & $\begin{array}{l}(+) \text { Water demands for all } \\
\text { major crop types are } \\
\text { estimated on } 0.5^{\circ} \text { grid } \\
(+) \text { Availability of water } \\
\text { at grid-scale affects } \\
\text { rainfed and irrigated crop } \\
\text { yields and thus land } \\
\text { allocation } \\
(+) \text { Agricultural trade } \\
\text { affects regional water use } \\
\text { and land allocation (+): } \\
\text { Irrigated area can be } \\
\text { endogenously expanded } \\
\text { by investing in new } \\
\text { irrigation infrastructure } \\
(-) \text { No direct competition } \\
\text { for water among sectors } \\
\text { (-): Blue water availability } \\
\text { does not include } \\
\text { non-renewable } \\
\text { groundwater }\end{array}$ & $\begin{array}{l}\text { (+) Environmental flow } \\
\text { requirements (EFRs) are } \\
\text { represented } \\
(+) \text { Implications of land } \\
\text { pressures for loss of } \\
\text { forests and other } \\
\text { unmanaged land } \\
\text { (+) Nitrogen losses are } \\
\text { tracked } \\
\text { (-) Implications of future } \\
\text { resource management for } \\
\text { terrestrial/aquatic } \\
\text { ecosystem quality not } \\
\text { explicitly modeled }\end{array}$ & $\begin{array}{l}\text { (+) LPJmL provides } \\
\text { spatially-explicit crop } \\
\text { and pasture yields, } \\
\text { carbon stocks, water } \\
\text { flows and and irrigation } \\
\text { water requirements as } \\
\text { inputs to MAgPIE }\end{array}$ \\
\hline
\end{tabular}


Table 1. Cont

\begin{tabular}{|c|c|c|c|c|c|c|}
\hline Model & References & Water-Energy & Land-Energy & Water-Land & Ecosystem Impacts & Other Linked Models \\
\hline AIM/CGE & $\begin{array}{c}{[42,147,149,} \\
151]\end{array}$ & $\begin{array}{l}\text { (+) Simplified } \\
\text { representations of water } \\
\text { demands for energy } \\
\text { industries (e.g., water } \\
\text { demands for primary } \\
\text { energy production } \\
\text { (mining and drilling) } \\
\text { scale with production) } \\
\text { (+) Tracking of water } \\
\text { demands for electric } \\
\text { power generation } \\
\text { (+) Hydropower potential } \\
\text { based on the hydrological } \\
\text { module of H08 } \\
(-) \text { Energy demand } \\
\text { associated with water } \\
\text { sourcing, delivery and } \\
\text { treatment is not included } \\
\text { (-) Water demands for } \\
\text { energy extraction and } \\
\text { transport fuel production } \\
\text { not included } \\
\text { (-) Coarse resolution of } \\
\text { the energy sector } \\
\text { impedes representation } \\
\text { of localized water } \\
\text { constraints }\end{array}$ & $\begin{array}{l}\text { (+) Land-use and energy } \\
\text { modules are fully coupled so } \\
\text { that bioenergy competes } \\
\text { directly with other land-based } \\
\text { mitigation strategies } \\
\text { (+) Land allocation for biomass } \\
\text { production competes with land } \\
\text { for other purposes. } \\
\text { (+) AFOLU emissions and } \\
\text { sinks are represented with } \\
\text { endogenous trade-offs between } \\
\text { energy and land-based } \\
\text { mitigation } \\
\text { (+) Energy price feedbacks on } \\
\text { land use decisions } \\
(-) \text { Biomass from forest residues } \\
\text { and managed natural forests } \\
\text { not represented (except } \\
\text { traditional biomass) } \\
\text { (-) Land requirements of } \\
\text { energy sector besides biomass } \\
\text { not included }\end{array}$ & $\begin{array}{l}\text { (+) Water demands for all } \\
\text { major crop types are } \\
\text { estimated on } 0.5^{\circ} \text { grid } \\
\text { (+) Availability of water } \\
\text { at grid-scale affects crop } \\
\text { yields and thus land } \\
\text { allocation } \\
\text { (-) Agricultural trade is } \\
\text { not influenced by } \\
\text { regional water constraints } \\
\text { (-) Future infrastructure } \\
\text { assumptions (irrigated } \\
\text { area and efficiency) are } \\
\text { exogenous } \\
\text { (-) No direct competition } \\
\text { for water among sectors } \\
\text { (-): Blue water availability } \\
\text { does not include } \\
\text { non-renewable } \\
\text { groundwater }\end{array}$ & $\begin{array}{l}(+) \text { Tracking of thermal } \\
\text { pollution from electricity } \\
\text { generation } \\
(+) \text { Implications of land } \\
\text { pressures for loss of } \\
\text { forests and other } \\
\text { unmanaged land } \\
(+) \text { Biodiversity impacts } \\
\text { can be explored with } \\
\text { linkage to } \\
\text { AIM/Biodiversity } \\
\text { (-) Implications of future } \\
\text { resource management for } \\
\text { terrestrial/aquatic } \\
\text { ecosystem quality not } \\
\text { explicitly modeled }\end{array}$ & $\begin{array}{l}\text { (+) GGCs (CYGMA and } \\
\text { LPJML) provide crop } \\
\text { yields as inputs to AIM } \\
\text { (+) Hydrological model } \\
\text { H08 can provide water } \\
\text { scarcity index with inputs } \\
\text { from AIM/CGE }\end{array}$ \\
\hline
\end{tabular}




\section{Limitations and Opportunities}

\subsection{Fine Resolution Representation of Water and Energy}

Given that land, energy, and water resources are heterogeneous in space and time, it is important that nexus assessments are conducted at fine temporal and spatial resolution. Although global crop, hydrological, and agro-economic models can operate at fine spatial resolution (most commonly on a 30- or 5-arcminute grid), no global spatially-explicit energy-economic or hydro-economic models currently exist (Figure 1). Such models are needed to evaluate the implications of local resource constraints for energy and water supply chains and to better understand how spatial reallocation of resources via distribution networks compare with other response strategies. In addition, closing the "resolution gap" would facilitate direct linkages with GHMs and GGCs as well as among sectoral economic models by standardizing the spatial resolution at which they operate. A fine-resolution energy-economic model would evaluate how local resource constraints might impact future energy system transformations, including those required to achieve climate change mitigation targets. It would be linked to hydro- and agro-economic modules to account for the energy used by these sectors as well as the water and land resources required by energy pathways. In addition, the model would explicitly represent energy distribution networks, such as pipelines and transmission grids, to evaluate how reallocation can alleviate energy constraints. By coupling agro-, hydro-, and energy-economic models, we can examine how constraints on one resource can be alleviated by the application of another resource. For example, how would regional water scarcity be resolved given the option of energy-and capital-intensive strategies, such as desalination and water conveyance? A major challenge for the development of spatial models is the availability of globally-comprehensive data at the appropriate resolution and the convergence on a common decision-making scale for resources managed at different administrative levels.

Developing and linking global high-resolution frameworks is a grand challenge because of the significant data requirements and computational complexity associated with spatially-explicit long-term planning problems [160]. Alternative (inexact) solution methods using heuristics and machine learning methods may provide an efficient way to optimize multi-sector development at continental- and global-scales. There is an important role that earth observation data can have in mitigating data requirements of models, e.g., by assessing cropland and crop types at fine spatial scales [38]; and by modelling river runoff and discharge, as well as droughts and their incidence [161].

\subsection{Keeping Track of Energy and Land}

There is limited accounting of the land requirements associated with the energy and water supply systems in global models. The non-bioenergy land requirements associated with the energy sector could increase with a shift to more distributed renewable energy systems, such as wind and solar, but it is unlikely (although uncertain) if such a large-scale transformation will come in direct conflict with agricultural and natural land. For example, beyond the direct land footprint, energy infrastructure can fragment terrestrial ecosystems [162]. Apart from bioenergy and reservoirs used for water storage and hydroelectricity, the land use impacts associated with the water and energy sectors are expected to be small. However, the land requirements of future reservoirs should be incorporated into the nexus framework as they may have significant consequences for human displacement, land degradation and biodiversity loss [163].

\subsection{Resource Redistribution}

Several studies indicate the importance of resource redistribution in alleviating localized resource constraints, including via trade [68,93,102] and electricity transmission [164-166], and water conveyance [62]. Thus, infrastructure that allows for the movement of commodities and resources from resource-rich to resource-poor locations stands out as one of the most important nexus solutions. While global economic models do represent trade at the macro-regional scale, they do not explicitly 
represent the sub-national and international distribution infrastructure that could also be important in addressing resource scarcity. Furthermore, as the spatial resolution of assessments becomes finer, the inclusion of distribution infrastructure becomes even more important in assessing how connections among spatial units can alleviate hotspots, particularly in cities [62,65]. Although the development of distribution infrastructure (e.g., roads, electricity transmission, and water conveyance) could yield huge benefits in developing countries, these projects are typically expensive and nexus models could be used to prioritize investments [167]. In general, improving connectivity can help to better distribute spatially heterogeneous resources over larger distances and enable more sustainable solutions.

\subsection{Enhanced Representation of Ecosystem Quality}

Current global nexus models incorporate minimum environmental flow requirements, agricultural expansion constraints, and forest conservation policies as proxies for ecosystem preservation $[28,68,80,97]$. However, this approach operates under the assumption that reserving sufficient quantities of water and land for aquatic and terrestrial ecosystems is enough to prevent degradation. Yet, habitat quality is also important for assessing environmental degradation and is strongly impacted by human activities and resource management $[72,168]$. For example, chemical and thermal pollution from the agricultural and energy sectors can have detrimental impacts on water quality and aquatic ecosystems even when the quantity of water is sufficient. Similarly, biomass collection for cooking and the harvesting of forest residues for commercial-scale bioenergy do not necessarily cause deforestation, but can degrade the quality of forest habitat with implications for biodiversity. While WorldQual provides a framework for tracking in-stream water pollutant concentrations [71], current global economic models have limited representation of resource management impacts on habitat quality and thus further model development is needed in this area [112]. This task will be challenging as the impacts will be site-specific and will depend on both the management practice and the sensitivity of the disturbed habitat. A scalable assessment framework that can be adapted to local circumstances and data would be helpful in this endeavor [73].

\subsection{Considering Regional Financial and Institutional Constraints}

With enough money, many local resource constraints can be addressed through large investments in technology and infrastructure (e.g., water conveyance networks, desalination plants, agricultural intensification, and energy infrastructure) [169]. However, weak institutions and limited financial resources may restrict access to credit, commodity markets, and technology and prohibit adequate investment in $R \& D$ and the requisite infrastructure in less developed and rural regions [87]. Global models need to reflect this reality by incorporating better methods for identifying regions and populations for which there are insufficient institutions and financial resources to address nexus challenges.

Many of the reviewed global agro- and energy-economic models represent food and energy demands at the level of large multi-country regions. Thus, even though there are substantial income differences within these regions, there is just one representative consumer with one price elasticity of demand for each commodity and region. Moreover, it is generally assumed that agricultural producers within each region have equal access to international markets and yield-improving technologies despite vast heterogeneity in financial resources, market access, and risk tolerance. Consequently, national and sub-national differences in the adaptive capacity of consumers and producers are not considered and this omission likely leads to an overestimation of the potential for adaptation and poverty reduction in global models [87,170].

To improve global nexus models, a better understanding of the spatial distribution of income groups, their food, water, and energy consumption, and the implications of consumer and producer heterogeneity for regional adaptation is necessary. This will require downscaling of food, water, and energy demands using more sophisticated methods than used in the past with explicit consideration of rural/urban, income, and climate differences. A more nuanced representation of resource demands 
and producer heterogeneity would improve the assessment of regionally-appropriate solutions as well as help quantify the international aid and/or subsidies required to overcome domestic financial constraints, improve resource access, and reduce poverty.

Moreover, sub-regional differences in governance are not well represented in global models even though these differences can greatly impact several factors that are important for enhancing adaptive capacity, such as property rights security, access to affordable lending rates, and investments into $\mathrm{R} \& \mathrm{D}$ and infrastructure. While one study applies differential lending rates at the macro-regional scale to explore the implications of governance for investments into yield-improving technologies and thus cropland expansion and deforestation [171], global models must be further developed to better incorporate the role of governance at the national scale and to account for anticipated changes in governance over time.

\subsection{Capturing Multi-Sector Vulnerabilities and Adaptation Options}

Most hotspot analyses identify how a single challenge or problem is distributed through space and time. Yet, in the WEL nexus, several challenges across multiple sectors (e.g., food/energy/water scarcity, land degradation, and biodiversity loss) are assessed simultaneously. Therefore, the development of approaches for identifying and communicating areas with multiple hotspots are needed [172,173]. In addition, traditional hotspot analysis is static in that vulnerable areas are identified under particular drivers. However, dynamic analyses in which hotspots are identified under various response strategies would be useful for illustrating how hotspots evolve when single solutions or portfolios of solutions are implemented. Such an approach could help to highlight how solutions in one sector may have unforeseen synergies or trade-offs with other sectors and how solutions for one location might shift challenges to other locations. In essence, solutions may cool down one hotspot but heat up another. A dynamic cross-sectoral approach would provide more realistic estimates of populations living in multi-sectoral hotspots, inform where solutions are needed, and help to identify synergistic strategies for alleviating hotspots and attaining sustainable development goals. Climate extremes and the representation in climate impact models is also an area where improvement is needed to assess the influence on multi-sector nexus solutions [16].

\subsection{Scalable and Integrated Models}

Existing nexus models are generally developed by linking pre-existing sectoral models. Yet integrating sectoral models is challenging as they often use inconsistent software platforms, suffer from mismatched spatial and temporal scales, and rely on disciplinary language that can be difficult for those from other disciplines to understand [174]. These challenges often lead to soft-linking, downor upscaling of shared datasets, and compromises in the representation of one or many sectors. To develop a truly integrated nexus framework, a coordinated approach is preferred in which sectoral models are co-developed with consistent spatial and temporal resolutions, software, programming languages, and databases [7]. This approach will facilitate the development of fully-integrated and hard-linked frameworks in which all sectors are equally represented and evaluated holistically at a global-scale.

Moreover, certain research questions may require finer spatial and temporal resolution than others and thus global frameworks should also be designed to be scalable so that consistent and efficient analyses can be conducted at sub-national scales [157]. Diverse behavioral responses at local scales may also be incorporated in future research using agent-based models for quantifying future water, energy and food demands [175]. The use of globally-comprehensive datasets will facilitate comparable assessments across not only scales, but also regions. Bridging multiple spatial scales will be challenging for decision-making models due to the computation complexity of distributed resource systems [160]. While nexus frameworks should be capable of independent analysis, enabling linkages with other established climate and I\&V models, such as global hydrological models, general circulation models and global gridded crop models should be kept in mind during development. 
Each model type contributes to uncertainties, and although model linking has in the past provided a framework for developing consistent scenarios, there are also potential risks of cascading uncertainties leading to a wide range of results $[54,176]$. Uncertainties across data, scale and assumptions can be communicated using multi-model assessments of transformation pathways [10]. Likewise, risks from uncertainties in key parameters can be incorporated into transformation decision-making in global models using a stochastic implementation $[177,178]$. Nevertheless, the complexity of the systems and diversity of the solutions means global solution modelers will need to explore a wide range of possible futures to ensure uncertainty is accurately characterized and communicated [179-181].

\section{Conclusions}

In this paper, we reviewed existing global models that focus on integrating water-energy-land system solutions and highlight several promising opportunities for future research. The results indicate that enhancements to the existing fleet of global tools are needed in the following areas: (1) improving the temporal and spatial resolution of techno-economic models for the energy and water sectors; (2) balancing energy and land requirements across sectors; (3) integrated representation of the role of distribution infrastructure in alleviating resource challenges; (4) modeling of impacts on environmental quality; (5) improved representation of the implementation challenges stemming from regional financial and institutional capacity; (6) enabling dynamic multi-sectoral vulnerability and adaptation needs assessment under climate extremes; and (7) the development of fully-coupled assessment frameworks based on consistent, scalable, and regionally-transferable platforms.

Data availability is routinely viewed as a barrier for global models but is becoming less so due to the recent growth in asset-level geospatial datasets derived from open access and remotely sensed data sources. Data size and computational speed are emerging as critical challenges for global modelers and the institutions that support them. Efficient solution algorithms and database management schemes are needed to address the analytical challenges identified in this review.

Author Contributions: N.J. and S.P. coordinated the review activities and wrote the initial manuscript. P.B., E.B., G.F., M.F., S.F., P.H., M.H., J.H., V.K., S.L., N.N., A.P. (Amanda Palazzo), A.P. (Alexander Popp), K.R., M.v.D., M.T.H.v.V., D.P.v.V., Y.W., D.W., B.W. and C.Z. reviewed literature and edited the manuscript.

Funding: This research was funded by Global Environment Facility (GEF) Project ID 6993: Integrated Solutions for Water, Energy, and Land (IS-WEL).

Acknowledgments: We acknowledge the Global Environment Facility (GEF) and the United Nations Industrial Development Organisation (UNIDO) for supporting the development and completion of this review as part of the scoping process of the Integrated Solutions for Water, Energy, and Land (IS-WEL) project.

Conflicts of Interest: The authors declare no conflicts of interest.

\section{References}

1. Valin, H.; Sands, R.D.; van der Mensbrugghe, D.; Nelson, G.C.; Ahammad, H.; Blanc, E.; Bodirsky, B.; Fujimori, S.; Hasegawa, T.; Havlik, P.; et al. The future of food demand: Understanding differences in global economic models. Agric. Econ. 2014, 45, 51-67. [CrossRef]

2. Bauer, N.; Calvin, K.; Emmerling, J.; Fricko, O.; Fujimori, S.; Hilaire, J.; Eom, J.; Krey, V.; Kriegler, E.; Mouratiadou, I.; et al. Shared Socio-Economic Pathways of the Energy Sector-Quantifying the Narratives. Glob. Environ. Chang. 2017, 42, 316-330. [CrossRef]

3. Popp, A.; Calvin, K.; Fujimori, S.; Havlik, P.; Humpenöder, F.; Stehfest, E.; Bodirsky, B.L.; Dietrich, J.P.; Doelmann, J.C.; Gusti, M.; et al. Land-use futures in the shared socio-economic pathways. Glob. Environ. Chang. 2017, 42, 331-345. [CrossRef]

4. Hanasaki, N.; Fujimori, S.; Yamamoto, T.; Yoshikawa, S.; Masaki, Y.; Hijioka, Y.; Kainuma, M.; Kanamori, Y.; Masui, T.; Takahashi, K.; et al. A global water scarcity assessment under Shared Socio-economic Pathways-Part 1: Water use. Hydrol. Earth Syst. Sci. 2013, 17, 2375-2391. [CrossRef] 
5. Wada, Y.; Flörke, M.; Hanasaki, N.; Eisner, S.; Fischer, G.; Tramberend, S.; Satoh, Y.; Van Vliet, M.T.; Yillia, P.; Ringler, C.; et al. Modeling global water use for the 21st century: The Water Futures and Solutions (WFaS) initiative and its approaches. Geosci. Model Dev. 2016, 9, 175-222. [CrossRef]

6. Hoff, H. Understanding the Nexus. In Proceedings of the Bonn 2011 Conference: The Water, Energy, and Food Security Nexus, Bonn, Nordrhein-Westfalen, Germany, 16-18 November 2011.

7. Howells, M.; Hermann, S.; Welsch, M.; Bazilian, M.; Segerström, R.; Alfstad, T.; Gielen, D.; Rogner, H.; Fischer, G.; Van Velthuizen, H.; et al. Integrated analysis of climate change, land-use, energy and water strategies. Nat. Clim. Chang. 2013, 3, 621-626. [CrossRef]

8. Cameron, C.; Pachauri, S.; Rao, N.D.; Mccollum, D.; Rogelj, J.; Riahi, K. Policy trade-offs between climate mitigation and clean cook-stove access in South Asia. Nat. Energy 2016, 1, 15010. [CrossRef]

9. Fujimori, S.; Hasegawa, T.; Krey, V.; Riahi, K.; Bertram, C.; Bodirsky, B.L.; Bosetti, V.; Callen, J.; Després, J.; Doelman, J.; et al. A multi-model assessment of food security implications of climate change mitigation. Nat. Sustain. 2019, 2, 386-396. [CrossRef]

10. Clarke, L.; Jiang, K.; Akimoto, K.; Babiker, M.; Blanford, G.; Fisher-Vanden, K.; Hourcade, J.C.; Krey, V.; Kriegler, E.; Loschel, A.; et al. Chapter 6-Assessing transformation pathways. In Climate Change 2014: Mitigation of Climate Change; IPCC Working Group III Contribution to AR5; Cambridge University Press: Cambridge, UK; New York, NY, USA, 2014.

11. Van Vuuren, D.P.; Kok, M.; Lucas, P.L.; Prins, A.G.; Alkemade, R.; Berg, M.V.D.; Bouwman, L.; Van Der Esch, S.; Jeuken, M.; Kram, T.; et al. Pathways to achieve a set of ambitious global sustainability objectives by 2050: Explorations using the IMAGE integrated assessment model. Technol. Soc. Chang. 2015, 98, 303-323. [CrossRef]

12. Hasegawa, T.; Havlík, P.; Frank, S.; Palazzo, A.; Valin, H. Tackling food consumption inequality to fight hunger without pressuring the environment. Nat. Sustain. 2019, 2, 826-833. [CrossRef]

13. Parkinson, S.; Krey, V.; Huppmann, D.; Kahil, T.; Mccollum, D.; Fricko, O.; Byers, E.; Gidden, M.J.; Mayor, B.; Khan, Z.; et al. Balancing clean water-climate change mitigation trade-offs. Environ. Res. Lett. 2019, 14, 014009. [CrossRef]

14. Krey, V. Global energy-climate scenarios and models: A review. Wiley Interdiscip. Rev. Energy Environ. 2014, 3, 363-383. [CrossRef]

15. Riahi, K.; Van Vuuren, D.P.; Kriegler, E.; Edmonds, J.; O’Neill, B.C.; Fujimori, S.; Bauer, N.; Calvin, K.; Dellink, R.; Fricko, O.; et al. The Shared Socioeconomic Pathways and their energy, land use, and greenhouse gas emissions implications: An overview. Glob. Environ. Chang. 2017, 42, 153-168. [CrossRef]

16. Schewe, J.; Gosling, S.N.; Reyer, C.; Zhao, F.; Ciais, P.; Elliott, J.; Francois, L.; Huber, V.; Lotze, H.K.; Seneviratne, S.I.; et al. State-of-the-art global models underestimate impacts from climate extremes. Nat. Commun. 2019, 10, 1005-1015. [CrossRef] [PubMed]

17. Müller, C.; Elliott, J.; Kelly, D.; Arneth, A.; Balkovic, J.; Ciais, P.; Deryng, D.; Folberth, C.; Hoek, S.; Izaurralde, R.C.; et al. The Global Gridded Crop Model Intercomparison phase 1 simulation dataset. Sci. Data 2019, 6, 50. [CrossRef] [PubMed]

18. Zhou, X.; Moinuddin, M. Sustainable Development Goals Interlinkages and Network Analysis: A Practical Tool for SDG Integration and Policy Coherence; Institute for Global Environmental Strategies (IGES): Hayama, Japan, 2017.

19. Liu, J.; Mooney, H.; Hull, V.; Davis, S.J.; Gaskell, J.; Hertel, T.; Lubchenco, J.; Seto, K.C.; Gleick, P.; Kremen, C.; et al. Systems integration for global sustainability. Science 2015, 347, 1258832. [CrossRef] [PubMed]

20. Bondeau, A.; Smith, P.C.; Zaehle, S.; Schaphoff, S.; Lucht, W.; Cramer, W.; Gerten, D.; Lotze-Campen, H.; Müller, C.; Reichstein, M.; et al. Modelling the role of agriculture for the 20th century global terrestrial carbon balance. Glob. Chang. Boil. 2007, 13, 679-706. [CrossRef]

21. Rost, S.; Gerten, D.; Bondeau, A.; Lucht, W.; Rohwer, J.; Schaphoff, S. Agricultural green and blue water consumption and its influence on the global water system. Water Resour. Res. 2008, 44, 09405. [CrossRef]

22. Izaurralde, R.; Williams, J.; McGill, W.; Rosenberg, N.; Jakas, M.Q. Simulating soil C dynamics with EPIC: Model description and testing against long-term data. Ecol. Model. 2006, 192, 362-384. [CrossRef]

23. Deryng, D.; Sacks, W.J.; Barford, C.C.; Ramankutty, N. Simulating the effects of climate and agricultural management practices on global crop yield. Glob. Biogeochem. Cycles 2011, 25. [CrossRef] 
24. Fischer, G.; van Velthuizen, H.; Shah, M.; Nachtergaele, F. Global Agro-Ecological Assessment for Agriculture in the 21st Century: Methodology and Results; International Institute for Applied Systems Analysis RR-02-02; International Institute for Applied Systems Analysis: Laxenburg, Austria, 2002.

25. Rosenzweig, C.; Elliott, J.; Deryng, D.; Ruane, A.C.; Müller, C.; Arneth, A.; Boote, K.J.; Folberth, C.; Glotter, M.; Khabarov, N.; et al. Assessing agricultural risks of climate change in the 21st century in a global gridded crop model intercomparison. Proc. Natl. Acad. Sci. USA 2014, 111, 3268-3273. [CrossRef] [PubMed]

26. Elliott, J.; Deryng, D.; Müller, C.; Frieler, K.; Konzmann, M.; Gerten, D.; Glotter, M.; Flörke, M.; Wada, Y.; Best, N.; et al. Constraints and potentials of future irrigation water availability on agricultural production under climate change. Proc. Natl. Acad. Sci. USA 2014, 111, 3239-3244. [CrossRef] [PubMed]

27. Jägermeyr, J.; Gerten, D.; Schaphoff, S.; Heinke, J.; Lucht, W.; Rockström, J. Integrated crop water management might sustainably halve the global food gap. Environ. Res. Lett. 2016, 11, 025002. [CrossRef]

28. Bonsch, M.; Popp, A.; Biewald, A.; Rolinski, S.; Schmitz, C.; Weindl, I.; Stevanovic, M.; Högner, K.; Heinke, J.; Ostberg, S.; et al. Environmental flow provision: Implications for agricultural water and land-use at the global scale. Glob. Environ. Chang. 2015, 30, 113-132. [CrossRef]

29. Fitton, N.; Alexander, P.; Arnell, N.; Bajzelj, B.; Calvin, K.; Doelman, J.; Gerber, J.; Havlik, P.; Hasegawa, T.; Herrero, M.; et al. The vulnerabilities of agricultural land and food production to future water scarcity. Glob. Environ. Chang. 2019, 58, 101944. [CrossRef]

30. Müller, C.; Robertson, R.D. Projecting future crop productivity for global economic modeling. Agric. Econ. 2014, 45, 37-50. [CrossRef]

31. Van Vuuren, D.P.; Edmonds, J.; Kainuma, M.; Riahi, K.; Thomson, A.; Hibbard, K.; Hurtt, G.C.; Kram, T.; Krey, V.; Lamarque, J.-F.; et al. The representative concentration pathways: An overview. Clim. Chang. 2011, 109, 5-31. [CrossRef]

32. Van Meijl, H.; Havlík, P.; Lotze-Campen, H.; Stehfest, E.; Witzke, P.; Domínguez, I.P.; Bodirsky, B.L.; Van Dijk, M.; Doelman, J.; Fellmann, T.; et al. Comparing impacts of climate change and mitigation on global agriculture by 2050. Environ. Res. Lett. 2018, 13, 064021. [CrossRef]

33. Rounsevell, M.D.A.; Arneth, A.; Alexander, P.; Brown, D.G.; De Noblet-Ducoudre, N.; Ellis, E.; Finnigan, J.; Galvin, K.; Grigg, N.; Harman, I.; et al. Towards decision-based global land use models for improved understanding of the Earth system. Earth Syst. Dyn. 2014, 5, 117-137. [CrossRef]

34. Alexander, P.; Rabin, S.; Anthoni, P.; Henry, R.; Pugh, T.A.M.; Rounsevell, M.D.A.; Arneth, A. Adaptation of global land use and management intensity to changes in climate and atmospheric carbon dioxide. Glob. Chang. Boil. 2018, 24, 2791-2809. [CrossRef]

35. Lotze-Campen, H.; Müller, C.; Bondeau, A.; Rost, S.; Popp, A.; Lucht, W. Global food demand, productivity growth, and the scarcity of land and water resources: A spatially explicit mathematical programming approach. Agric. Econ. 2008, 39, 325-338. [CrossRef]

36. Havlik, P.; Schneider, U.A.; Schmid, E.; Böttcher, H.; Fritz, S.; Skalský, R.; Aoki, K.; De Cara, S.; Kindermann, G.; Kraxner, F.; et al. Global land-use implications of first and second generation biofuel targets. Energy Policy 2011, 39, 5690-5702. [CrossRef]

37. Jägermeyr, J.; Pastor, A.; Biemans, H.; Gerten, D. Reconciling irrigated food production with environmental flows for Sustainable Development Goals implementation. Nat. Commun. 2017, 8, 15900. [CrossRef] [PubMed]

38. Xiong, J.; Thenkabail, P.; Gumma, M.; Teluguntla, P.; Poehnelt, J.; Congalton, R.; Yadav, K.; Thau, D. Automated cropland mapping of continental Africa using Google Earth Engine cloud computing. ISPRS J. Photogramm. Remote Sens. 2017, 126, 225-244. [CrossRef]

39. Flörke, M.; Kynast, E.; Bärlund, I.; Eisner, S.; Wimmer, F.; Alcamo, J. Domestic and industrial water uses of the past 60 years as a mirror of socio-economic development: A global simulation study. Glob. Environ. Chang. 2013, 23, 144-156. [CrossRef]

40. Schmied, H.M.; Eisner, S.; Franz, D.; Wattenbach, M.; Portmann, F.T.; Flörke, M.; Doll, P. Sensitivity of simulated global-scale freshwater fluxes and storages to input data, hydrological model structure, human water use and calibration. Hydrol. Earth Syst. Sci. Discuss. 2014, 11, 1583-1649. [CrossRef]

41. Sutanudjaja, E.; van Beek, L.; Wanders, N.; Wada, Y.; Bosmans, J.H.; Drost, N.; Van Der Ent, R.J.; De Graaf, I.E.; Hoch, J.M.; De Jong, K.; et al. PCR-GLOBWB 2: A 5 arcmin global hydrological and water resources model. Geosci. Model Dev. 2018, 11, 2429-2453. [CrossRef] 
42. Hanasaki, N.; Fujimori, S.; Yamamoto, T.; Yoshikawa, S.; Masaki, Y.; Hijioka, Y.; Kainuma, M.; Kanamori, Y.; Masui, T.; Takahashi, K.; et al. A global water scarcity assessment under Shared Socio-economic Pathways-Part 2: Water availability and scarcity. Hydrol. Earth Syst. Sci. 2013, 17, 2393-2413. [CrossRef]

43. Vörösmarty, C.; Federer, C.; Schloss, A. Potential evaporation functions compared on US watersheds: Possible implications for global-scale water balance and terrestrial ecosystem modeling. J. Hydrol. 1998, 207, 147-169. [CrossRef]

44. Hejazi, M.I.; Edmonds, J.; Clarke, L.; Kyle, P.; Davies, E.; Chaturvedi, V.; Wise, M.; Patel, P.; Eom, J.; Calvin, K. Integrated assessment of global water scarcity over the 21st century under multiple climate change mitigation policies. Hydrol. Earth Syst. Sci. 2014, 18, 2859-2883. [CrossRef]

45. Alcamo, J.; Flörke, M.; Maerker, M. Future long-term changes in global water resources driven by socio-economic and climatic changes. Hydrol. Sci. J. 2007, 52, 247-275. [CrossRef]

46. Bijl, D.L.; Bogaart, P.W.; Kram, T.; De Vries, B.J.; Van Vuuren, D.P. Long-term water demand for electricity, industry and households. Environ. Sci. Policy 2016, 55, 75-86. [CrossRef]

47. Wada, Y.; De Graaf, I.E.M.; Van Beek, L.P.H. High-resolution modeling of human and climate impacts on global water resources. J. Adv. Model. Earth Syst. 2016, 8, 735-763. [CrossRef]

48. Wada, Y.; Wisser, D.; Eisner, S.; Flörke, M.; Masaki, Y.; Portmann, F.T.; Stacke, T.; Tessler, Z.; Schewe, J.; Gerten, D.; et al. Multimodel projections and uncertainties of irrigation water demand under climate change. Geophys. Res. Lett. 2013, 40, 4626-4632. [CrossRef]

49. van Vliet, M.T.H.; Wiberg, D.; LeDuc, S.; Riahi, K. Power-generation system vulnerability and adaptation to changes in climate and water resources. Nat. Clim. Chang. 2016, 6, 375-380. [CrossRef]

50. Vörösmarty, C.J. Global Water Resources: Vulnerability from Climate Change and Population Growth. Science 2000, 289, 284-288. [CrossRef]

51. Rockstrom, J.; Falkenmark, M.; Karlberg, L.; Hoff, H.; Rost, S.; Gerten, D. Future water availability for global food production: The potential of green water for increasing resilience to global change. Water Resour. Res. 2009, 45, 12. [CrossRef]

52. Parkinson, S.C.; Johnson, N.; Rao, N.D.; Jones, B.; Van Vliet, M.T.; Fricko, O.; Djilali, N.; Riahi, K.; Flörke, M. Climate and human development impacts on municipal water demand: A spatially-explicit global modeling framework. Environ. Model. Softw. 2016, 85, 266-278. [CrossRef]

53. Schewe, J.; Heinke, J.; Gerten, D.; Haddeland, I.; Arnell, N.W.; Clark, D.B.; Dankers, R.; Eisner, S.; Fekete, B.M.; Colón-González, F.J.; et al. Multimodel assessment of water scarcity under climate change. Proc. Natl. Acad. Sci. USA 2014, 111, 3245-3250. [CrossRef]

54. Greve, P.; Kahil, T.; Mochizuki, J.; Schinko, T.; Satoh, Y.; Burek, P.; Fischer, G.; Tramberend, S.; Burtscher, R.; Langan, S.; et al. Global assessment of water challenges under uncertainty in water scarcity projections. Nat. Sustain. 2018, 1, 486-494. [CrossRef]

55. Zhou, Q.; Hanasaki, N.; Fujimori, S.; Masaki, Y.; Hijioka, Y. Economic consequences of global climate change and mitigation on future hydropower generation. Clim. Chang. 2017, 147, 77-90. [CrossRef]

56. Turner, S.W.; Hejazi, M.; Kim, S.H.; Clarke, L.; Edmonds, J. Climate impacts on hydropower and consequences for global electricity supply investment needs. Energy 2017, 141, 2081-2090. [CrossRef]

57. Falchetta, G.; Gernaat, D.E.; Hunt, J.; Sterl, S. Hydropower dependency and climate change in sub-Saharan Africa: A nexus framework and evidence-based review. J. Clean. Prod. 2019, 231, 1399-1417. [CrossRef]

58. Fricko, O.; Parkinson, S.C.; Johnson, N.; Strubegger, M.; Van Vliet, M.T.H.; Riahi, K. Energy sector water use implications of a $2{ }^{\circ} \mathrm{C}$ climate policy. Environ. Res. Lett. 2016, 11, 034011. [CrossRef]

59. Oki, T.; Agata, Y.; Kanae, S.; Saruhashi, T.; Yang, D.; Musiake, K. Global assessment of current water resources using total runoff integrating pathways. Hydrol. Sci. J. 2001, 46, 983-995. [CrossRef]

60. Qin, Y.; Mueller, N.D.; Siebert, S.; Jackson, R.B.; AghaKouchak, A.; Zimmerman, J.B.; Tong, D.; Hong, C.; Davis, S.J. Flexibility and intensity of global water use. Nat. Sustain. 2019, 2, 515-523. [CrossRef]

61. Stokes, J.R.; Horvath, A. Energy and Air Emission Effects of Water Supply. Environ. Sci. Technol. 2009, 43, 2680-2687. [CrossRef]

62. McDonald, R.I.; Weber, K.; Padowski, J.; Flörke, M.; Schneider, C.; Green, P.A.; Gleeson, T.; Eckman, S.; Lehner, B.; Balk, D.; et al. Water on an urban planet: Urbanization and the reach of urban water infrastructure. Glob. Environ. Chang. 2014, 27, 96-105. [CrossRef] 
63. Hejazi, M.; Edmonds, J.; Clarke, L.; Kyle, P.; Davies, E.; Chaturvedi, V.; Wise, M.; Patel, P.; Eom, J.; Calvin, K.; et al. Long-term global water projections using six socioeconomic scenarios in an integrated assessment modeling framework. Technol. Forecast. Soc. Chang. 2014, 81, 205-226. [CrossRef]

64. Wada, Y.; Bierkens, M.F.P. Sustainability of global water use: Past reconstruction and future projections. Environ. Res. Lett. 2014, 9, 104003. [CrossRef]

65. Flörke, M.; Schneider, C.; McDonald, R.I. Water competition between cities and agriculture driven by climate change and urban growth. Nat. Sustain. 2018, 1, 51-58. [CrossRef]

66. Laizé, C.L.R.; Acreman, M.C.; Schneider, C.; Dunbar, M.J.; Houghton-Carr, H.A.; Flörke, M.; Hannah, D.M. Projected flow alteration and ecological risk for pan-european rivers. River Res. Appl. 2014, 30, $299-314$. [CrossRef]

67. Pastor, A.V.; Ludwig, F.; Biemans, H.; Hoff, H.; Kabat, P. Accounting for environmental flow requirements in global water assessments. Hydrol. Earth Syst. Sci. 2014, 18, 5041-5059. [CrossRef]

68. Pastor, A.V.; Palazzo, A.; Havlik, P.; Biemans, H.; Wada, Y.; Obersteiner, M.; Kabat, P.; Ludwig, F. The global nexus of food-trade-water sustaining environmental flows by 2050. Nat. Sustain. 2019, 2, 499-507. [CrossRef]

69. Bijl, D.L.; Biemans, H.; Bogaart, P.W.; Dekker, S.C.; Doelman, J.C.; Stehfest, E.; Vuuren, D.P.; Van Vuuren, D.P. A Global Analysis of Future Water Deficit Based on Different Allocation Mechanisms. Water Resour. Res. 2018, 54, 5803-5824. [CrossRef]

70. Bouwman, A.F.; Beusen, A.H.W.; Billen, G. Human alteration of the global nitrogen and phosphorus soil balances for the period 1970-2050. Glob. Biogeochem. Cycles 2009, 23. [CrossRef]

71. Voß, A.; Alcamo, J.; Bärlund, I.; Voß, F.; Kynast, E.; Williams, R.; Malve, O. Continental scale modelling of in-stream river water quality: A report on methodology, test runs, and scenario application. Hydrol. Process. 2012, 26, 2370-2384. [CrossRef]

72. van Vliet, M.T.H.; Flörke, M.; Wada, Y. Quality matters for water scarcity. Nat. Geosci. 2017, 10, 800. [CrossRef]

73. Strokal, M.; Spanier, J.E.; Kroeze, C.; Koelmans, A.A.; Flörke, M.; Franssen, W.; Hofstra, N.; Langan, S.; Tang, T.; Van Vliet, M.T.; et al. Global multi-pollutant modelling of water quality: Scientific challenges and future directions. Curr. Opin. Environ. Sustain. 2019, 36, 116-125. [CrossRef]

74. Seitzinger, S.P.; Harrison, J.A.; Dumont, E.; Beusen, A.H.W.; Bouwman, A.F. Sources and delivery of carbon, nitrogen, and phosphorus to the coastal zone: An overview of Global Nutrient Export from Watersheds (NEWS) models and their application. Glob. Biogeochem. Cycles 2005, 19. [CrossRef]

75. Reder, K.; Flörke, M.; Alcamo, J. Modeling historical fecal coliform loadings to large European rivers and resulting in-stream concentrations. Environ. Model. Softw. 2015, 63, 251-263. [CrossRef]

76. Reder, K.; Barlund, I.; Voß, A.; Kynast, E.; Williams, R.; Malve, O.; Flörke, M. European scenario studies on future in-stream nutrient concentrations. Trans. ASABE 2013, 56, 1407-1417.

77. Tang, T.; Strokal, M.; Van Vliet, M.T.; Seuntjens, P.; Burek, P.; Kroeze, C.; Langan, S.; Wada, Y. Bridging global, basin and local-scale water quality modeling towards enhancing water quality management worldwide. Curr. Opin. Environ. Sustain. 2019, 36, 39-48. [CrossRef]

78. Scanlon, B.R.; Zhang, Z.; Save, H.; Sun, A.Y.; Schmied, H.M.; Van Beek, L.P.H.; Wiese, D.N.; Wada, Y.; Long, D.; Reedy, R.C.; et al. Global models underestimate large decadal declining and rising water storage trends relative to GRACE satellite data. Proc. Natl. Acad. Sci. USA 2018, 115, E1080-E1089. [CrossRef]

79. Havlik, P.; Valin, H.; Herrero, M.; Obersteiner, M.; Schmid, E.; Rufino, M.C.; Mosnier, A.; Thornton, P.K.; Böttcher, H.; Conant, R.T.; et al. Climate change mitigation through livestock system transitions. Proc. Natl. Acad. Sci. USA 2014, 111, 3709-3714. [CrossRef]

80. Popp, A.; Humpenöder, F.; Weindl, I.; Bodirsky, B.L.; Bonsch, M.; Lotze-Campen, H.; Müller, C.; Biewald, A.; Rolinski, S.; Stevanovic, M.; et al. Land-use protection for climate change mitigation. Nat. Clim. Chang. 2014, 4, 1095-1098. [CrossRef]

81. Calvin, K.; Patel, P.; Clarke, L.; Asrar, G.; Bond-Lamberty, B.; Cui, R.Y.; Di Vittorio, A.; Dorheim, K.; Edmonds, J.; Hartin, C.; et al. GCAM v5. 1: representing the linkages between energy, water, land, climate, and economic systems. Geosci. Model Dev. 2019, 12, 677-698. [CrossRef] 
82. Kim, S.H.; Hejazi, M.; Liu, L.; Calvin, K.; Clarke, L.; Edmonds, J.; Kyle, P.; Patel, P.; Wise, M.; Davies, E. Balancing global water availability and use at basin scale in an integrated assessment model. Clim. Chang. 2016, 136, 217-231. [CrossRef]

83. Stehfest, E.; van Vuuren, D.P.; Kram, T.; Bouwman, L.; Alkemade, R.; Bakkenes, M.; Biemans, H.; Bouwman, A.; den Elzen, M.; Janse, J.; et al. Integrated Assessment of Global Environmental Change with IMAGE: Model Description and Policy Applications; PBL Netherlands Environmental Assessment Agency: The Hague, The Netherlands, 2014.

84. Cai, X.; Rosegrant, M.W. Global Water Demand and Supply Projections. Water Int. 2002, 27, 159-169. [CrossRef]

85. Rosegrant, M.W.; Ringler, C.; Msangi, S.; Sulser, T.B.; Zhu, T.; Cline, S.A. International Model for Policy Analysis of Agricultural Commodities and Trade (IMPACT): Model Description; International Food Policy Research Institute (IFPRI): Washington, DC, USA, 2008.

86. Cohn, A.S.; Mosnier, A.; Havlík, P.; Valin, H.; Herrero, M.; Schmid, E.; O’Hare, M.; Obersteiner, M. Cattle ranching intensification in Brazil can reduce global greenhouse gas emissions by sparing land from deforestation. Proc. Natl. Acad. Sci. USA 2014, 111, 7236-7241. [CrossRef]

87. Hertel, T.W.; Lobell, D.B. Agricultural adaptation to climate change in rich and poor countries: Current modeling practice and potential for empirical contributions. Energy Econ. 2014, 46, 562-575. [CrossRef]

88. Schmitz, C.; van Meijl, H.; Kyle, P.; Nelson, G.C.; Fujimori, S.; Gurgel, A.; Havlik, P.; Heyhoe, E.; d'Croz, D.M.; Popp, A.; et al. Land-use change trajectories up to 2050: Insights from a global agro-economic model comparison. Agric. Econ. 2014, 45, 69-84. [CrossRef]

89. von Lampe, M.; Willenbockel, D.; Ahammad, H.; Blanc, E.; Cai, Y.; Calvin, K.; Fujimori, S.; Hasegawa, T.; Havlik, P.; Heyhoe, E.; et al. Why do global long-term scenarios for agriculture differ? An overview of the AgMIP global economic model intercomparison. Agric. Econ. 2014, 45, 3-20. [CrossRef]

90. Rao, N.; Poblete-Cazenave, M.; Bhalerao, R.; Davis, K.; Parkinson, S. Spatial analysis of energy use and GHG emissions from cereal production in India. Sci. Total Environ. 2019, 654, 841-849. [CrossRef] [PubMed]

91. LeClere, D.; Havlik, P.; Fuss, S.; Schmid, E.; Mosnier, A.; Walsh, B.; Valin, H.; Herrero, M.; Khabarov, N.; Obersteiner, M. Climate change induced transformations of agricultural systems: Insights from a global model. Environ. Res. Lett. 2014, 9, 124018. [CrossRef]

92. Schmitz, C.; Gerten, D.; Dietrich, J.P.; Bodirsky, B.; Biewald, A.; Popp, A.; Lotze-Campen, H.; Lotze-Campen, H. Blue water scarcity and the economic impacts of future agricultural trade and demand. Water Resour. Res. 2013, 49, 3601-3617. [CrossRef]

93. Stevanović, M.; Popp, A.; Lotze-Campen, H.; Dietrich, J.P.; Müller, C.; Bonsch, M.; Schmitz, C.; Bodirsky, B.L.; Humpenöder, F.; Weindl, I. The impact of high-end climate change on agricultural welfare. Sci. Adv. 2016, 2, e1501452. [CrossRef]

94. Jalava, M.; Guillaume, J.H.; Kummu, M.; Porkka, M.; Siebert, S.; Varis, O. Diet change and food loss reduction: What is their combined impact on global water use and scarcity? Earth's Future 2016, 4, 62-78. [CrossRef]

95. Lotze-Campen, H.; von Lampe, M.; Kyle, P.; Fujimori, S.; Havlik, P.; van Meijl, H.; Hasegawa, T.; Popp, A.; Schmitz, C.; Tabeau, A.; et al. Impacts of increased bioenergy demand on global food markets: An AgMIP economic model intercomparison. Agric. Econ. 2014, 45, 103-116. [CrossRef]

96. Popp, A.; Dietrich, J.P.; Lotze-Campen, H.; Klein, D.; Bauer, N.; Krause, M.; Beringer, T.; Gerten, D.; Edenhofer, O. The economic potential of bioenergy for climate change mitigation with special attention given to implications for the land system. Environ. Res. Lett. 2011, 6, 034017. [CrossRef]

97. Kraxner, F.; Nordström, E.-M.; Havlík, P.; Gusti, M.; Mosnier, A.; Frank, S.; Valin, H.; Fritz, S.; Fuss, S.; Kindermann, G.; et al. Global bioenergy scenarios - Future forest development, land-use implications, and trade-offs. Biomass Bioenergy 2013, 57, 86-96. [CrossRef]

98. Dietrich, J.P.; Schmitz, C.; Lotze-Campen, H.; Popp, A.; Müller, C. Forecasting technological change in agriculture-An endogenous implementation in a global land use model. Technol. Soc. Chang. 2014, 81, 236-249. [CrossRef]

99. Bonsch, M.; Humpenöder, F.; Popp, A.; Bodirsky, B.; Dietrich, J.P.; Rolinski, S.; Biewald, A.; Lotze-Campen, H.; Weindl, I.; Gerten, D.; et al. Trade-offs between land and water requirements for large-scale bioenergy production. GCB Bioenergy 2016, 8, 11-24. [CrossRef] 
100. Nelson, G.C.; Valin, H.; Sands, R.D.; Havlík, P.; Ahammad, H.; Deryng, D.; Elliott, J.; Fujimori, S.; Hasegawa, T.; Heyhoe, E.; et al. Climate change effects on agriculture: Economic responses to biophysical shocks. Proc. Natl. Acad. Sci. USA 2014, 111, 3274-3279. [CrossRef] [PubMed]

101. Rosenzweig, C.; Jones, J.; Hatfield, J.; Ruane, A.; Boote, K.; Thorburn, P.; Antle, J.; Nelson, G.; Porter, C.; Janssen, S.; et al. The Agricultural Model Intercomparison and Improvement Project (AgMIP): Protocols and pilot studies. Agric. Meteorol. 2013, 170, 166-182. [CrossRef]

102. Wiebe, K.; Lotze-Campen, H.; Sands, R.; Tabeau, A.; van der Mensbrugghe, D.; Biewald, A.; Bodirsky, B.; Islam, S.; Kavallari, A.; Mason-D'Croz, D.; et al. Climate change impacts on agriculture in 2050 under a range of plausible socioeconomic and emissions scenarios. Environ. Res. Lett. 2015, 10, 085010. [CrossRef]

103. Valin, H.; Havlik, P.; Mosnier, A.; Herrero, M.; Schmid, E.; Obersteiner, M. Agricultural productivity and greenhouse gas emissions: Trade-offs or synergies between mitigation and food security? Environ. Res. Lett. 2013, 8, 035019. [CrossRef]

104. Frank, S.; Havlík, P.; Stehfest, E.; van Meijl, H.; Witzke, P.; Pérez-Domínguez, I.; van Dijk, M.; Doelman, J.C.; Fellmann, T.; Koopman, J.F.; et al. Agricultural non- $\mathrm{CO}_{2}$ emission reduction potential in the context of the $1.5^{\circ} \mathrm{C}$ target. Nat. Clim. Chang. 2019, 9, 66-73. [CrossRef]

105. Davis, K.F.; Rulli, M.C.; Seveso, A.; D'Odorico, P. Increased food production and reduced water use through optimized crop distribution. Nat. Geosci. 2017, 10,919-924. [CrossRef]

106. Scheelbeek, P.F.D.; Bird, F.A.; Tuomisto, H.L.; Green, R.; Harris, F.B.; Joy, E.J.M.; Chalabi, Z.; Allen, E.; Haines, A.; Dangour, A.D. Effect of environmental changes on vegetable and legume yields and nutritional quality. Proc. Natl. Acad. Sci. USA 2018, 115, 6804-6809. [CrossRef]

107. Hasegawa, T.; Fujimori, S.; Havlík, P.; Valin, H.; Bodirsky, B.L.; Doelman, J.C.; Fellmann, T.; Kyle, P.; Koopman, J.F.L.; Lotze-Campen, H.; et al. Risk of increased food insecurity under stringent global climate change mitigation policy. Nat. Clim. Chang. 2018, 8, 699-703. [CrossRef]

108. Rose, S.K.; Kriegler, E.; Bibas, R.; Calvin, K.; Popp, A.; van Vuuren, D.P.; Weyant, J. Bioenergy in energy transformation and climate management. Clim. Chang. 2014, 123, 477-493. [CrossRef]

109. Klein, D.; Luderer, G.; Kriegler, E.; Strefler, J.; Bauer, N.; Leimbach, M.; Popp, A.; Dietrich, J.; Humpenöder, F.; Lotze-Campen, H.; et al. The value of bioenergy in low stabilization scenarios: An assessment using REMIND-MAgPIE. Clim. Chang. 2014, 123, 705-718. [CrossRef]

110. Chaturvedi, V.; Hejazi, M.; Edmonds, J.; Clarke, L.; Kyle, P.; Davies, E.; Wise, M. Climate mitigation policy implications for global irrigation water demand. Mitig. Adapt. Strat. Glob. Chang. 2013, 20, $389-407$. [CrossRef]

111. Mouratiadou, I.; Biewald, A.; Pehl, M.; Bonsch, M.; Baumstark, L.; Klein, D.; Popp, A.; Luderer, G.; Kriegler, E. The impact of climate change mitigation on water demand for energy and food: An integrated analysis based on the Shared Socioeconomic Pathways. Environ. Sci. Policy 2016, 64, 48-58. [CrossRef]

112. Meller, L.; van Vuuren, D.; Cabeza, M. Quantifying biodiversity impacts of climate change and bioenergy: The role of integrated global scenarios. Reg. Environ. Chang. 2015, 15, 961-971. [CrossRef]

113. Alkemade, R.; Van Oorschot, M.; Miles, L.; Nellemann, C.; Bakkenes, M.; Brink, B.T. GLOBIO3: A Framework to Investigate Options for Reducing Global Terrestrial Biodiversity Loss. Ecosystems 2009, 12, 374-390. [CrossRef]

114. IEA. Water for Energy - Is Energy Becoming a Thirstier Resource (Excerpt from the World Energy Outlook 2012), World Energy Outlook 2012; International Energy Agency (IEA): Paris, France, 2012; p. 33.

115. International Institute for Applied Systems Analysis (2015) SSP Database (Shared Socioeconomic Pathways)—Version 1.0. Available online: https://ntcat.iiasa.ac.at/SspDb (accessed on 24 August 2018).

116. Webster, M.; Donohoo, P.; Palmintier, B. Water- $\mathrm{CO}_{2}$ trade-offs in electricity generation planning. Nat. Clim. Chang. 2013, 3, 1029-1032. [CrossRef]

117. Dubreuil, A.; Assoumou, E.; Bouckaert, S.; Selosse, S.; Maïzi, N. Water modeling in an energy optimization framework-The water-scarce middle east context. Appl. Energy 2013, 101, 268-279. [CrossRef]

118. Davies, E.G.; Kyle, P.; Edmonds, J.A. An integrated assessment of global and regional water demands for electricity generation to 2095. Adv. Water Resour. 2013, 52, 296-313. [CrossRef]

119. Kyle, P.; Davies, E.G.; Dooley, J.J.; Smith, S.J.; Clarke, L.E.; Edmonds, J.A.; Hejazi, M. Corrigendum to "Influence of climate change mitigation technology on global demands of water for electricity generation". Int. J. Greenh. Gas Control. 2013, 17, 549-552. [CrossRef] 
120. Popp, A.; Rose, S.K.; Calvin, K.; Van Vuuren, D.P.; Dietrich, J.P.; Wise, M.; Stehfest, E.; Humpenöder, F.; Kyle, P.; Van Vliet, J.; et al. Land-use transition for bioenergy and climate stabilization: Model comparison of drivers, impacts and interactions with other land use based mitigation options. Clim. Chang. 2014, 123, 495-509. [CrossRef]

121. Hejazi, M.I.; Voisin, N.; Liu, L.; Bramer, L.M.; Fortin, D.C.; Hathaway, J.E.; Huang, M.; Kyle, P.; Leung, L.R.; Li, H.-Y.; et al. 21st century United States emissions mitigation could increase water stress more than the climate change it is mitigating. Proc. Natl. Acad. Sci. USA 2015, 112, 10635-10640. [CrossRef] [PubMed]

122. Turner, S.W.; Hejazi, M.; Calvin, K.; Kyle, P.; Kim, S. A pathway of global food supply adaptation in a world with increasingly constrained groundwater. Sci. Total Environ. 2019, 673, 165-176. [CrossRef] [PubMed]

123. Elimelech, M.; Phillip, W.A. The Future of Seawater Desalination: Energy, Technology, and the Environment. Science 2011, 333, 712-717. [CrossRef]

124. Walker, R.V.; Beck, M.; Hall, J.; Dawson, R.; Heidrich, O. The energy-water-food nexus: Strategic analysis of technologies for transforming the urban metabolism. J. Environ. Manag. 2014, 141, 104-115. [CrossRef]

125. Stillwell, A.S.; Webber, M.E. Geographic, Technologic, And Economic Analysis of Using Reclaimed Water for Thermoelectric Power Plant Cooling. Environ. Sci. Technol. 2014, 48, 4588-4595. [CrossRef]

126. Brook, B.W.; Sodhi, N.S.; Bradshaw, C.J. Synergies among extinction drivers under global change. Trends Ecol. Evol. 2008, 23, 453-460. [CrossRef]

127. Bellard, C.; Bertelsmeier, C.; Leadley, P.; Thuiller, W.; Courchamp, F. Impacts of climate change on the future of biodiversity. Ecol. Lett. 2012, 15, 365-377. [CrossRef]

128. Dudgeon, D.; Arthington, A.H.; Gessner, M.O.; Kawabata, Z.-I.; Knowler, D.J.; Lévêque, C.; Naiman, R.J.; Prieur-Richard, A.-H.; Soto, D.; Stiassny, M.L.J.; et al. Freshwater biodiversity: Importance, threats, status and conservation challenges. Biol. Rev. 2006, 81, 163-182. [CrossRef]

129. Nilsson, C.; Thompson, W.G.; Goldstein, S.L. Fragmentation and Flow Regulation of the World's Large River Systems. Science 2005, 308, 405-408. [CrossRef] [PubMed]

130. Alamanos, A.; Latinopoulos, D.; Papaioannou, G.; Mylopoulos, N. Integrated hydro-economic modeling for sustainable water resources management in data-scarce areas. Water Resour. Manag. 2019, 33, 2775-2790. [CrossRef]

131. Harou, J.J.; Pulido-Velazquez, M.; Rosenberg, D.E.; Medellín-Azuara, J.; Lund, J.R.; Howitt, R.E. Hydro-economic models: Concepts, design, applications, and future prospects. J. Hydrol. 2009, 375, 627-643. [CrossRef]

132. Young, R.; Haveman, R. Economics of Water Resources: A Survey. In Handbook of Natural Resource and Energy Economics, 2nd ed.; Kneese, A., Sweenly, J., Eds.; Elsevier Science Publishers: Oxford, UK, 2017; pp. 465-529.

133. Robinson, S.; Mason-D'Croz, D.; Zhu, T. The IMPACT Model: A Global Simulation Modelling System for Analysis of Water-Economy Links in Climate Change Scenarios; International Food Policy Research Institute: Washington, DC, USA, 2016.

134. Kahil, T.; Parkinson, S.; Satoh, Y.; Greve, P.; Burek, P.; Veldkamp, T.I.E.; Burtscher, R.; Byers, E.; Djilali, N.; Fischer, G.; et al. A Continental-Scale Hydroeconomic Model for Integrating Water-Energy-Land Nexus Solutions. Water Resour. Res. 2018, 54, 7511-7533. [CrossRef]

135. Fujimori, S.; Hanasaki, N.; Masui, T. Projections of industrial water withdrawal under shared socioeconomic pathways and climate mitigation scenarios. Sustain. Sci. 2017, 12, 275-292. [CrossRef]

136. Fujimori, S.; Hasegawa, T.; Masui, T. AIM/CGE V2.0: Basic Feature of the Model. In Post-2020 Climate Action; Springer Science and Business Media LLC: Berlin, Germany, 2017; pp. 305-328.

137. Taheripour, F.; Hertel, T.; Liu, J. Introducing Water by River Basin into the GTAP-BIO Model: GTAP-BIO-W; GTAP Working Paper 77; Center for Global Trade Analysis, Department of Agricultural Economics, Purdue University: Washington DC, USA, 2013.

138. Strzepek, K.; Schlosser, A.; Gueneau, A.; Gao, X.; Blanc, É.; Fant, C.; Rasheed, B.; Jacoby, H.D. Modeling water resource systems within the framework of the MIT Integrated Global System Model: IGSM-WRS. J. Adv. Model. Earth Syst. 2013, 5, 638-653. [CrossRef]

139. Davies, E.G.; Simonovic, S.P. ANEMI: A new model for integrated assessment of global change. Interdiscip. Environ. Rev. 2010, 11, 127. [CrossRef] 
140. Giampietro, M.; Mayumi, K.; Ramos-Martin, J. Multi-scale integrated analysis of societal and ecosystem metabolism (MuSIASEM): Theoretical concepts and basic rationale. Energy 2009, 34, 313-322. [CrossRef]

141. Hertel, T.W. Global Trade Analysis: Modeling and Applications; Cambridge University Press: Cambridge, UK, 1997.

142. Taheripour, F.; Hertel, T.W.; Liu, J. The role of irrigation in determining the global land use impacts of biofuels. Energy Sustain. Soc. 2013, 3, 4. [CrossRef]

143. Liu, J.; Hertel, T.W.; Taheripour, F.; Zhu, T.; Ringler, C. International trade buffers the impact of future irrigation shortfalls. Glob. Environ. Chang. 2014, 29, 22-31. [CrossRef]

144. Babiker, M.H.; Reilly, J.M.; Mayer, M.; Eckaus, R.S.; Sue Wing, I.; Hyman, R.C. The MIT Emissions Prediction and Policy Analysis (EPPA) Model: Revisions, Sensitivities, and Comparisons of Results; MIT JPSPGC Report 71; MIT: Cambridge, MA, USA, 2001.

145. Chen, Y.-H.H.; Paltsev, S.; Reilly, J.M.; Morris, J.F.; Babiker, M.H. Long-term economic modeling for climate change assessment. Econ. Model. 2016, 52, 867-883. [CrossRef]

146. Fujimori, S.; Su, X.; Liu, J.-Y.; Hasegawa, T.; Takahashi, K.; Masui, T.; Takimi, M. Implication of Paris Agreement in the context of long-term climate mitigation goals. SpringerPlus 2016, 5, 1620. [CrossRef] [PubMed]

147. Fujimori, S.; Hasegawa, T.; Masui, T.; Takahashi, K.; Herran, D.S.; Dai, H.; Hijioka, Y.; Kainuma, M. SSP3: AIM implementation of Shared Socioeconomic Pathways. Glob. Environ. Chang. 2017, 42, 268-283. [CrossRef]

148. Fujimori, S.; Masui, T.; Matsuoka, Y. Development of a global computable general equilibrium model coupled with detailed energy end-use technology. Appl. Energy 2014, 128, 296-306. [CrossRef]

149. Fujimori, S.; Hasegawa, T.; Masui, T.; Takahashi, K. Land use representation in a global CGE model for long-term simulation: CET vs. logit functions. Food Secur. 2014, 6, 685-699. [CrossRef]

150. Reilly, J.; Melillo, J.; Cai, Y.; Kicklighter, D.; Gurgel, A.; Paltsev, S.; Cronin, T.; Sokolov, A.; Schlosser, A. Using Land to Mitigate Climate Change: Hitting the Target, Recognizing the Trade-offs. Environ. Sci. Technol. 2012, 46, 5672-5679. [CrossRef] [PubMed]

151. Hasegawa, T.; Fujimori, S.; Ito, A.; Takahashi, K.; Masui, T. Global land-use allocation model linked to an integrated assessment model. Sci. Total Environ. 2017, 580, 787-796. [CrossRef]

152. Schlosser, C.A.; Strzepek, K.; Gao, X.; Gueneau, A.; Fant, C.; Paltsev, S.; Rasheed, B.; Smith-Greico, T.; Blanc, É.; Jacoby, H.D.; et al. The Future of Global Water Stress: An Integrated Assessment; MIT Joint Program on the Science and Policy of Global Change, Report No. 254; MIT: Cambridge, CA, USA, 2014.

153. Fricko, O.; Havlik, P.; Rogelj, J.; Klimont, Z.; Gusti, M.; Johnson, N.; Kolp, P.; Strubegger, M.; Valin, H.; Amann, M.; et al. The marker quantification of the Shared Socioeconomic Pathway 2: A middle-of-the-road scenario for the 21st century. Glob. Environ. Chang. 2017, 42, 251-267. [CrossRef]

154. Hoegh-Guldberg, O.; Jacob, D.; Taylor, M.; Bindi, M.; Brown, S.; Camilloni, I.; Diedhiou, A.; Djalante, R.; Ebi, K.; Engelbrecht, F.; et al. Chapter 3: Impacts of $1.5^{\circ} \mathrm{C}$ global warming on natural and human systems. In Global Warming of $1.5^{\circ} \mathrm{C}$ an IPCC Special Report on the Impacts of Global Warming of $1.5^{\circ} \mathrm{C}$ Above Pre-industrial Levels and Related Global Greenhouse Gas Emission Pathways, in the Context of Strengthening the Global Response to the Threat of Climate Change; Intergovernmental Panel on Climate Change: Cambridge, UK, 2018.

155. Rogelj, J.; Shindell, D.; Jiang, K.; Fifita, S.; Forster, P.; Ginzburg, V.; Handa, C.; Kheshgi, H.; Kobayashi, K.; Kriegler, E.; et al. Chapter 2: Mitigation pathways compatible with $1.5^{\circ} \mathrm{C}$ in the context of sustainable development. In Global Warming of $1.5^{\circ} \mathrm{C}$ an IPCC Special Report on the Impacts of Global Warming of $1.5^{\circ} \mathrm{C}$ above Pre-industrial Levels and Related Global Greenhouse Gas Emission Pathways, in the Context of Strengthening the Global Response to the Threat of Climate Change; Intergovernmental Panel on Climate Change: Cambridge, $\mathrm{UK}, 2018$.

156. Wise, M.; Calvin, K.; Thomson, A.; Clarke, L.; Bond-Lamberty, B.; Sands, R.; Smith, S.J.; Janetos, A.; Edmonds, J. Implications of Limiting $\mathrm{CO}_{2}$ Concentrations for Land Use and Energy. Science 2009, 324, 1183-1186. [CrossRef]

157. Bijl, D.L.; Bogaart, P.W.; Dekker, S.C.; van Vuuren, D.P. Unpacking the Nexus: Different Spatial Scales for Water, Food, and Energy. Glob. Environ. Chang. 2017, 48, 22-31. [CrossRef]

158. Wise, M.; Calvin, K. GCAM 3.0 Agriculture and Land Use: Technical Description of Modeling Approach; Pacific Northwest National Laboratory PNNL-20971; Pacific Northwest National Laboratory: Richland, WA, USA, 2011. 
159. Collins, W.D.; Craig, A.P.; Truesdale, J.E.; Di Vittorio, A.V.; Jones, A.D.; Bond-Lamberty, B.; Calvin, K.V.; Edmonds, J.A.; Kim, S.H.; Thomson, A.M.; et al. The integrated Earth system model version 1: Formulation and functionality. Geosci. Model Dev. 2015, 8, 2203-2219. [CrossRef]

160. Eftelioglu, E.; Jiang, Z.; Ali, R.; Shekhar, S. Spatial computing perspective on food energy and water nexus. J. Environ. Stud. Sci. 2016, 6, 62-76. [CrossRef]

161. Gleason, C.J.; Wada, Y.; Wang, J. A Hybrid of Optical Remote Sensing and Hydrological Modeling Improves Water Balance Estimation. J. Adv. Model. Earth Syst. 2018, 10, 2-17. [CrossRef]

162. Jordaan, S.M.; Keith, D.W.; Stelfox, B. Quantifying land use of oil sands production: A life cycle perspective. Environ. Res. Lett. 2009, 4, 024004. [CrossRef]

163. Liu, L.; Parkinson, S.; Gidden, M.; Byers, E.; Satoh, Y.; Riahi, K.; Forman, B.; Byers, E.A. Quantifying the potential for reservoirs to secure future surface water yields in the world's largest river basins. Environ. Res. Lett. 2018, 13, 044026. [CrossRef]

164. Macknick, J.; Cohen, S.; Newmark, R.; Martinez, A.; Sullivan, P.; Tidwell, V. Water Constraints in an Electric Sector Capacity Expansion Model; Technical Report, NREL/TP-6A20-64270; National Renewable Energy Laboratory: Golden, CO, USA, 2015.

165. Parkinson, S.C.; Djilali, N.; Krey, V.; Fricko, O.; Johnson, N.; Khan, Z.; Sedraoui, K.; Almasoud, A.H. Impacts of Groundwater Constraints on Saudi Arabia's Low-Carbon Electricity Supply Strategy. Environ. Sci. Technol. 2016, 50, 1653-1662. [CrossRef] [PubMed]

166. Wang, Y.; Byers, E.; Parkinson, S.; Wanders, N.; Wada, Y.; Mao, J.; Bielicki, J.M. Vulnerability of existing and planned coal-fired power plants in Developing Asia to changes in climate and water resources. Energy Environ. Sci. 2019, 12, 3164-3181. [CrossRef]

167. Conway, D.; Dalin, C.; Landman, W.A.; Osborn, T.J. Hydropower plans in eastern and southern Africa increase risk of concurrent climate-related electricity supply disruption. Nat. Energy 2017, 2, 946-953. [CrossRef]

168. UNEP. A Snapshot of the World's Water Quality: Towards a Global Assessment; United Nations Environment Programme: Nairobi, Kenya, 2016; p. 162.

169. Vörösmarty, C.J.; McIntyre, P.B.; Gessner, M.O.; Dudgeon, D.; Prusevich, A.; Green, P.; Glidden, S.; Bunn, S.E.; Sullivan, C.A.; Liermann, C.R.; et al. Global threats to human water security and river biodiversity. Nature 2010, 467, 555-561. [CrossRef]

170. Hussein, Z.; Hertel, T.; Golub, A. Climate change mitigation policies and poverty in developing countries. Environ. Res. Lett. 2013, 8, 035009. [CrossRef]

171. Wang, X.; Biewald, A.; Dietrich, J.P.; Schmitz, C.; Lotze-Campen, H.; Humpenöder, F.; Bodirsky, B.L.; Popp, A. Taking account of governance: Implications for land-use dynamics, food prices, and trade patterns. Ecol. Econ. 2016, 122, 12-24. [CrossRef]

172. Byers, E.; Gidden, M.; Leclère, D.; Balkovic, J.; Burek, P.; Ebi, K.L.; Greve, P.; Grey, D.; Havlík, P.; Hillers, A.; et al. Global exposure and vulnerability to multi-sector development and climate change hotspots. Environ. Res. Lett. 2018, 13, 055012. [CrossRef]

173. Piontek, F.; Müller, C.; Pugh, T.A.M.; Clark, D.B.; Deryng, D.; Elliott, J.; Colón González, F.d.J.; Flörke, M.; Folberth, C.; Franssen, W.; et al. Multisectoral climate impact hotspots in a warming world. Proc. Natl. Acad. Sci. USA 2014, 111, 3233-3238. [CrossRef] [PubMed]

174. Hibbard, K.A.; Janetos, A.C. The regional nature of global challenges: A need and strategy for integrated regional modeling. Clim. Chang. 2013, 118, 565-577. [CrossRef]

175. Arneth, A.; Brown, C.; Rounsevell, M.D.A. Global models of human decision-making for land-based mitigation and adaptation assessment. Nat. Clim. Chang. 2014, 4, 550-557. [CrossRef]

176. Beven, K.; Lamb, R. The uncertainty cascade in model fusion. Geol. Soc. 2017, 408, 255-266. [CrossRef]

177. Krey, V.; Riahi, K. Risk Hedging Strategies Under Energy System and Climate Policy Uncertainties. In Robustness Analysis in Decision Aiding, Optimization, and Analytics; Springer Science and Business Media LLC: Berlin, Germany, 2013; Volume 199, pp. 435-474.

178. Ermolieva, T.Y.; Ermoliev, Y.M.; Havlik, P.; Mosnier, A.; LeClere, D.; Kraksner, F.; Khabarov, N.; Obersteiner, M. Systems Analysis of Robust Strategic Decisions to Plan Secure Food, Energy, and Water Provision Based on the Stochastic Globiom Model. Cybern. Syst. Anal. 2015, 51, 125-133. [CrossRef]

179. Budescu, D.V.; Por, H.H.; Broomell, S.B. Effective communication of uncertainty in the IPCC reports. Clim. Chang. 2012, 113, 181-200. [CrossRef] 
180. McCollum, D.L.; Krey, V.; Riahi, K.; Kolp, P.; Grübler, A.; Makowski, M.; Nakicenovic, N. Climate policies can help resolve energy security and air pollution challenges. Clim. Chang. 2013, 119, 479-494. [CrossRef]

181. Lamontagne, J.R.; Reed, P.M.; Link, R.; Calvin, K.V.; Clarke, L.E.; Edmonds, J.A. Large Ensemble Analytic Framework for Consequence-Driven Discovery of Climate Change Scenarios. Earth's Future 2018, 6, 488-504. [CrossRef] article distributed under the terms and conditions of the Creative Commons Attribution (CC BY) license (http://creativecommons.org/licenses/by/4.0/). 